\title{
ARTICLES
}

\section{LGBT TAXPAYERS: A COLLISION OF "OTHERS"}

\author{
BY ANTHONY C. INFANTI*
}

\section{INTRODUCTION}

In this symposium, we are spending a day exploring the intersection of tax, gender, and sexuality. When the prominent critical race theorist Kimberle Crenshaw coined the term "intersectionality" more than twenty years ago, it appears that she had the metaphor of a crossroads in mind. Indeed, when describing how Black women are multiply disadvantaged by a combination of their gender and race, Crenshaw specifically drew upon this metaphor to make her point:

Consider an analogy to traffic in an intersection, coming and going in all four directions. Discrimination, like traffic through an intersection, may flow in one direction, and it may flow in another. If an accident happens in an intersection, it can be caused by cars traveling from any number of directions and, sometimes, from all of them. Similarly, if a Black woman is harmed because she is in the intersection, her injury could result from sex discrimination or race discrimination. ${ }^{1}$

In speaking of potential accidents that may occur at an intersection, Crenshaw highlights the violence inherent in all intersections. But, well before intersecting paths give rise to the possibility that individuals, vehicles, or even concepts traveling down these different paths might collide with each other, every intersection has always already been the product of an originary, violent collision of the paths themselves.

A trace-really, much more than a trace-of this originary violence can be found in the etymological roots of the word "intersection" itself. The verb "to intersect," of which "intersection" is the noun form, comes from the Latin intersecāre, "to cut asunder, intersect." Given the first of these two original meanings, it should come as little surprise that this Latin word is actually a combination of inter, "between," and secāre, "to cut." 3 Thus, it might be said that

\footnotetext{
* Professor of Law, University of Pittsburgh School of Law. Thanks to Jennifer Levi and Karen Loewy at Gay \& Lesbian Advocates \& Defenders for providing me copies of the parties' briefs in O'Donnabhain v. Commissioner, 134 T.C. 34 (2010). Thanks to Bridget Crawford for her helpful comments on an earlier draft of this essay. (C) 2012, Anthony C. Infanti.

1. Kimberle Crenshaw, Demarginalizing the Intersection of Race and Sex: A Black Feminist Critique of Antidiscrimination Doctrine, Feminist Theory and Antiracist Politics, 1989 U. CHI. Legal F. 139, 149.

2. 1 OXFORD ENGLISH DiCTIONARY 1468 (compact ed. 1971).

3. $I d$.
} 
intersecting paths do not merely (and harmlessly) cross each other; rather, of necessity, the two paths cut into each other to form or create a crossroads before continuing on their way. Intersectional violence, therefore, long pre-dates any potential collision that may occur at a crossroads, once created. A slash, a cleft, a gash — some sort of mark or scar-was, whether freshly made or created long ago, always already left by the cutting that was required to create the intersection that gave rise to the opportunity for yet further, future violent convergences between those traveling down the now intersecting paths.

In the case of the intersection of tax with sexual and gender identity, the originary intersectional violence is still ongoing. In other words, the intersection of tax with sexual and gender identity is still in the process of being created. The two paths are colliding, cutting into each other, leaving a freshly open wound that is bleeding and oozing and that still has not had time yet to heal into a scar marking this intersectional point.

In this essay, I explore the violent collision of these concepts-or, more appropriately, these two "others." I begin my exploration of this collision of "others" by first explaining how the lesbian, gay, bisexual, and transgender (LGBT) community is a marginalized "other" in American society while, in contrast, tax is a privileged "other" in the realm of American law. Then, I turn to a close examination of a recent case, O'Donnabhain $v$. Commissioner, ${ }^{4}$ to illustrate the collision of the otherness of LGBT individuals with the otherness of tax. This case exemplifies the originary violence that is, as we speak, hewing the concepts of tax and sexual and gender identity to create a point of intersection at which these concepts can, in the future, again and again violently collide with each other.

As Jacques Derrida has said, "Tout autre est tout autre." 5 Though much of the magical quality of the phrase is lost in translation, this phrase has been rendered in English as "Every other is completely other,"6 or, alternatively (and far more cumbersomely), "Every other (one) is every (bit) other." Derrida has, with his characteristic obliqueness, said of this phrase:

"Every other (one) is every (bit) other"- -the stakes seem to be altered by the trembling of this dictum. It is no doubt too economical, too elliptical, and hence, like any formula so isolated and capable of being transmitted out of context, too close to the coded language of a

4. 134 T.C. 34 (2010).

5. Jacques Derrida, The Gift of Death 82 (David Wills trans., Univ. of Chicago Press 1995) [hereinafter DERridA, GiFT of DEATH]. This is the title of a chapter of this book, in which Derrida contemplates the alterity both of God and every other person. Later, in the course of a meditation on death and the passage of borders (i.e., on what can be conceptualized as another intersection that can be fraught with violence), Derrida repeats the phrase in speaking of the singularity of each person's death. JACQUES Derrida, APORIas 22 (Thomas Dutoit trans., Stanford Univ. Press 1993) [hereinafter Derrida, APORIAS].

6. DERrida, ApOrIAS, supra note 5, at 22.

7. DERrida, GIFT OF DEATH, supra note 5, at 82. 
password. One uses it to play with the rules, to cut someone or something short, to aggressively circumscribe a domain of discourse. It becomes the secret of all secrets. Is it not sufficient to transform what one complacently calls a context in order to demystify the shibboleth or decipher all the secrets of the world? ${ }^{8}$

As Derrida suggests, let us take the next short while "to play with the rules," "to cut someone or something short," and, even possibly, "to aggressively circumscribe a domain of discourse." ${ }^{\prime}$ Let us transform our context by exploring how tax, on the one hand, and sexual and gender identity, on the other, are so "completely"10 or "every (bit) other." "Let us consider how, despite being so distinctly different, the two concepts do share their difference in common. Let us bear witness as, notwithstanding (or, perhaps, because of) their common outsider status, these two concepts emerge as so profoundly and violently incompatible. ${ }^{12}$

\section{OTHERNESS}

\section{A. TOUT AUTRE ...}

To say that lesbians, gay men, bisexuals, and transgender persons, who collectively form the LGBT community, are treated in American society "as an undifferentiated 'other' that can be marginalized, demonized, stigmatized, or just forgotten" is to state the obvious. ${ }^{13}$ Nonetheless, it is worth recalling that the "otherness" of the LGBT community is deeply ingrained in our culture. As Professor Byrne Fone has documented in his book Homophobia: A History, ${ }^{14}$ Western society has a long-standing tradition of sexual prejudice. ${ }^{15}$

8. Id.

9. Id.

10. DERrida, Aporias, supra note 5, at 22.

11. Derrida, Gift of Death, supra note 5, at 82.

12. See id. at 83 .

We are not just playing here, turning this little sentence around in order to make it dazzle from every angle. We would only pay slight and bemused attention to this particular formula and to the form of this key if, in the discreet displacement that affects the functions of the two words there didn't appear, as if on the same musical scale, two alarmingly different themes [partitions, (musical) scores] that, through their disturbing likeness, emerge as incompatible.

Id.

13. Anthony C. Infanti, Everyday Law for Gays and Lesbians (and Those Who Care About THEM) 16 (2007).

14. Byrne Fone, Homophobia: A History (2000).

15. As I have explained elsewhere:

The word "homophobia" was coined by the psychologist George Weinberg in the late 1960s. This term has proven to be an effective rhetorical device for lesbians and gay men because it stands "a central assumption of heterosexual society on its head by locating the 'problem' of homosexuality not in homosexual people, but in heterosexuals who were intolerant of gay men and lesbians." Notwithstanding both its rhetorical power and its usefulness in drawing attention to antigay hostility, scholars and psychologists have criticized the term because of its 
Professor Fone traces the roots of Western sexual prejudice to the partial acceptance of homosexuality in Greece and Rome. ${ }^{16}$ By the end of Antiquity, even this limited acceptance of homosexuality eroded and was replaced with prohibitions on homosexual activity that eventually included the death penalty as punishment. ${ }^{17}$ Civil and ecclesiastical attempts to control homosexual activity increased "and homosexual acts generally came to be viewed as "heinous and occasionally [were] described as the worst of all sins." "18 "By the late Middle Ages, sodomy was no longer a sin that could be repented; it had become a sin without forgiveness. In the early thirteenth century, the Catholic Church called for civil (as well as ecclesiastical) punishment of sodomy." ${ }^{19}$ Though the full extent to which homosexual activity was persecuted during this time still remains unknown-after all, "sodomy was considered such a horrible crime that the records of sodomy trials "were sometimes burned with the guilty sodomite",20_ records of executions for sodomy date back as far as $1292 .^{21}$

The Renaissance was little better, as sodomy was criminalized throughout Europe and truly horrific punishments for homosexual acts were enacted, including castration and death by decapitation, hanging, or burning. ${ }^{22}$ During this period, "nearly sixteen thousand people were tried for sodomy ... [and] about four hundred men and women are known to have been executed" in Spain,

imprecision and ability to mislead. To remedy these problems, research psychologist Gregory Herek has broken antigay hostility down into three different categories: sexual stigma (i.e., "the shared knowledge of society's negative regard for any nonheterosexual behavior, identity, relationship or community"), heterosexism (i.e., "the cultural ideology that perpetuates sexual stigma by denying and denigrating any nonheterosexual form of behavior, identity, relationship, or community"), and sexual prejudice (i.e., "heterosexuals' negative attitudes toward homosexual behavior; people who engage in homosexual behavior or who identify as gay, lesbian, or bisexual; and communities of gay, lesbian, and bisexual people").

INFANTI, supra note 13, at 21-22 n.30 (quoting Gregory M. Herek, Beyond "Homophobia": Thinking About Sexual Prejudice and Stigma in the Twenty-first Century, 1 Sexuality Res. \& Soc. Pol'y 6, 8, 15-17 (2004) (citations omitted)). Given these critiques, I generally avoid the term "homophobia" except where another author has used it, opting instead for one of Herek's more precise terms. Id.

16. As I have summarized elsewhere:

In retrospect, Greece is often viewed "as a utopia in which homosexual love flourished without blame or censure"; however, Fone notes that the only homosexual activity accepted in ancient Greek society was that which conformed to, and reinforced, the primacy of the adult male citizen. Accordingly, "the adult male had the unquestioned right to penetrate and dominate his presumably weaker, usually younger, and socially inferior partner," who might be a younger man but not an underage boy. In contrast, it was not socially acceptable for an adult male to be effeminate, to accept the passive role in homosexual sex, or to engage exclusively in homosexual sex. Similar conventions prevailed in Roman society.

Id. at 10 (quoting Fone, supra note 14, at 17, 26-27).

17. See FonE, supra note 14 , at 60-71.

18. INFANTI, supra note 13, at 10 (quoting FonE, supra note 14, at 131 (footnote omitted)).

19. Id.

20. Id. at 10-11 (quoting FonE, supra note 14, at 174-75).

21. See Fone, supra note 14, at 144, 174.

22. See id. at 192-225. 
Portugal, France, Italy, and Geneva alone. ${ }^{23}$ "By the late eighteenth and early nineteenth centuries, many Western European nations had decriminalized sodomy; however, this decriminalization 'did not mean that intolerance of sodomites also disappeared." ${ }^{24}$ Still, England resisted the trend toward decriminalization. It retained "the death penalty for sodomy until 1861 and criminal sanctions for homosexual activity into the twentieth century." ${ }^{25}$

Shifting from the Old to the New World, sodomy was punishable by death during the colonial period in New England. ${ }^{26}$ There are records of men being executed as well as records of men being severely whipped, burned with a hot iron, and then made permanent outcasts for engaging in homosexual activity. ${ }^{27}$ Like England, the United States ignored the trend toward decriminalization. Many states abolished the death penalty for homosexual activity but retained their criminal prohibitions of sodomy, in some cases into the twenty-first century. ${ }^{28}$

Focusing more particularly on the status of members of the LGBT community as outlaws in the United States, Professor William Eskridge has published a series of law review articles documenting "the history of the legal treatment of homosexuality in the United States from the late nineteenth century through the early 1980s. ${ }^{29}$ In late-nineteenth- and early-twentieth-century America, arrests and convictions for "crimes against nature" rose, as did the use of other laws (e.g., those relating to disorderly conduct, vagrancy, loitering, indecent exposure, and solicitation) to regulate same-sex "degeneracy." 30 Professor Eskridge describes the chilling practical effects of this regulation of homosexual activity:

More important, the consequences of arrest and more certain conviction of crimes associated with homosexuality often had tragic collateral consequences: jail time (several years if convicted of sodomy), incarceration and physical torture in a mental institution under a sexual psychopath law, loss of one's job and even livelihood if the arrest were publicized, court-martial or (more typically) administrative separation

23. Id. at 214 .

24. INFANTI, supra note 13, at 11 (quoting Fone, supra note 14, at 266).

25. Id.

26. Id. at 329.

27. Id. at $329,331$.

28. Id. at 332; see Lawrence v. Texas, 539 U.S. 558 (2003) (striking down the remaining state sodomy laws).

29. INFANTI, supra note 13, at 11; see William N. Eskridge, Jr., Law and the Construction of the Closet: American Regulation of Same-Sex Intimacy, 1880-1946, 82 IowA L. Rev. 1007 (1997); William N. Eskridge, Jr., Privacy Jurisprudence and the Apartheid of the Closet, 1946-1961, 24 FLA. ST. U. L. REv. 703 (1997); William N. Eskridge, Jr., Challenging the Apartheid of the Closet: Establishing Conditions for Lesbian and Gay Intimacy, Nomos, and Citizenship, 1961-1981, 25 HofsTRA L. Rev. 817 (1997). The following summary of these articles is borrowed from INFANTI, supra note 13, at 11-12, with original footnotes renumbered to correspond to the numbering in this essay and other footnotes added in keeping with law review convention.

30. Eskridge, Law and Construction of the Closet, supra note 29, at 1016-17, 1032. 
from the armed forces, deportation if one were a noncitizen, and continued surveillance and harassment by police officers and detectives. The homosexual was not only a sexual outlaw, but one who by World War II had clearly caught the eye of the government. ${ }^{31}$

Tracking the medical discourse of the period, American social understanding of homosexual activity shifted from "the sinful sodomite to the degenerate invert... [and then] from the degenerate invert to the psychopathic homosexual." 32 Although the invert was considered a threat for challenging traditional gender roles (an invert might today be called gender nonconforming or a "gender bender"), the psychopathic homosexual was considered even more of a threat because he "was sexually out of control and even predatory" (think of the now well-worn stereotype of the homosexual as child molester). ${ }^{33}$ In view of the threat to society posed by homosexuality, the government sought to "expunge homosexuality from the nation's public culture... [through] censorship of homophile publications, theatrical productions, and movies that depicted 'sex perversion'; disruption of homosexual socialization by state raids on homosexual haunts and by regulation of liquor sales; and finally direct interrogation, treatment, and exclusion during World War II." ${ }^{34}$

In the postwar years, homosexuals were the object of witch hunts at the federal and state levels. As antihomosexual panics swept cities from Boise, Idaho, to Miami, Florida, vice squads vigorously pursued homosexuals through spying, decoys, and raids. ${ }^{35}$ In addition, an increasing number of states enacted sexual psychopath laws that permitted indefinite detention and psychiatric treatment of homosexuals-treatment that included lobotomies, electric shock aversion therapy, pharmacological shock (induced vomiting when homoerotic images were shown), and the injection of hormones. ${ }^{36}$ At the same time, the federal government attempted to eliminate homosexuals from civil service employment and military service, and it further attempted to exclude alien homosexuals from entering the United States. ${ }^{37}$ These federal witch hunts had a broader impact because the government shared information with private employers, who often blacklisted individuals discharged for being homosexual. ${ }^{38}$ Whether on their own or cued by the federal government, the states also began witch hunts for homosexuals. ${ }^{39}$

In the 1940s and 1950s, the federal government surveilled and harassed both

31. Id. at 1068-69 (footnote omitted).

32. Id. at 1054 .

33. $I d$.

34. Id. at 1069.

35. Eskridge, Privacy Jurisprudence, supra note 29, at 717-33.

36. Id. at 713-16.

37. Id. at 733-46.

38. Id. at 743 .

39. Id. at 746 . 
individual homosexuals and homosexual organizations, and state and local governments attempted to suppress homosexual socialization by raiding gay bars and revoking their liquor licenses. ${ }^{40}$ During this period, the federal and state governments also censored homosexual publications. Films were subjected to several layers of censorship: The federal government impounded foreign films dealing with homosexuality, the motion-picture industry adopted a voluntary censorship code that prohibited reference to homosexuality in films distributed domestically, and state and local licensing laws prohibited films dealing with homosexuality. ${ }^{41}$

This barrage of police persecution, government employment discrimination, exclusion of homosexual aliens, suppression of homosexual socialization, and censorship of homosexual materials did not abate until the 1960s and 1970s. ${ }^{42}$ Notwithstanding that the LGBT movement gathered steam following the Stonewall uprising in $1969^{43}$ and began to make remarkable strides, ${ }^{44}$ the LGBT community continued (and continues) to be marginalized and stigmatized. For example, it was not until 2003 that the U.S. Supreme Court finally struck down the last of the state criminal prohibitions against consensual homosexual sex. ${ }^{45}$ Anti-LGBT bias crimes continue to occur at high rates-and transgender and other gender nonconforming persons find themselves disproportionately targeted. ${ }^{46}$ Moreover, the LGBT community is still seen "as some disembodied and dehumanized 'other' that can be vilified and scapegoated for society's problems." ${ }^{\text {"47 }}$ In the past decade alone, the LGBT community has found itself blamed for (1) natural disasters, as it was in the wake of Hurricane Katrina; ${ }^{48}$ (2) the

40. Id. at $754-57,761-66$.

41. Id. at 757-61.

42. See generally Eskridge, Challenging the Apartheid of the Closet, supra note 29.

43. Elizabeth Armstrong has provocatively challenged the conventional wisdom that the 1969 Stonewall uprising was the catalyst for gay liberation. ElizABEth A. Armstrong, Forging GaY IDENTities: Organizing SeXuality IN SAN Francisco, 1950-1994, at 56-80 (2002).

44. For a description both of how far the LGBT movement has come over the past several decades and of how far it still has to go to achieve equality and acceptance, see INFANTI, supra note 13, at 2-7.

45. See Lawrence v. Texas, 539 U.S. 558 (2003).

46. Nat'l Coal. of Anti-Violence Programs, Hate Violence Against the Lesbian, Gay, Bisexual, Transgender, and QueER Communities in the United States In 2009, at 4-5, 17 (2010), available at http://www.avp.org/documents/NCAVP2009HateViolenceReportforWeb_000.pdf (explaining that a decline in reported incidents in 2009 was likely due not to an actual decrease in incidents but to the effects of the economic downturn on the ability of agencies to obtain data and further explaining that transgender and other gender nonconforming persons "are particularly vulnerable to hate violence"). The number of anti-LGBT murders in 2009-even though lower than the number in 2008-was still the second highest number reported during the preceding ten years. Id. at 29 .

47. INFANTI, supra note 13 , at 8.

48. Tom Zeller, Jr., To Some, Katrina Was Mission Accomplished, N.Y. Times, Sept. 12, 2005, at C3 ("For others, the storm was simply a divine gay-bashing, with numerous Web sites taking it as no coincidence that Katrina landed just two days before the start of Southern Decadence 2005, the annual New Orleans celebration known informally as the Gay Mardi Gras."). 
September 11, 2001 terrorist attacks; ${ }^{49}$ and (3) John Kerry's loss in the 2004 presidential election. ${ }^{50}$ And the seemingly incessant bullying and bashing of LGBT others can have very real-and very tragic-consequences, as we witnessed in the spate of suicides by gay teens in fall $2010 .^{51}$

\section{B. ... ET TOUT AUTRE}

Tax, too, is an "other"- -but in a different, generally more positive sense of that word. That is, tax is not "other" in the sense of being outside, lesser, or marginalized; rather, it is "other" in the sense of being a unique and different area of the law, and often one that is seen as elevated, above the fray, or somehow on a higher plane. Put differently, tax is, as it is sometimes said, "exceptional." Tax exceptionalism manifests itself in a variety of different ways and contexts. In this section, I sketch a few examples of arguments and counterarguments about the position that tax occupies in the realm of American law to provide a sense of the pervasiveness of the notion of tax exceptionalism.

\section{Legislative History}

A trio of tax practitioners (one of whom had earlier been-and later was again-a Treasury official) has argued that the tax legislative process is sufficiently different from the process of creating legislation in other areas that tax legislative history should (subject to a few qualifications) be treated as an authoritative source of guidance concerning congressional intent. ${ }^{52}$ Recognizing that tax lawyers widely hold this view, Professor Karla Simon has argued that the tax legislative process is actually not all that unique and argues for a slightly

49. John F. Harris, God Gave U.S. “What We Deserve,” Falwell Says, WASH. Post, Sept. 14, 2001, at C3 ("Television evangelists Jerry Falwell and Pat Robertson, two of the most prominent voices of the religious right, said liberal civil liberties groups, feminists, homosexuals and abortion rights supporters bear partial responsibility for Tuesday's terrorist attacks because their actions have turned God's anger against America.").

50. Scott S. Greenberger, Gay-Marriage Ruling Pushed Voters Mobilized Bush, Left Kerry Wary, Boston Globe, Nov. 7, 2004, at B1 ("In the days after Tuesday's elections, conservative activists and some Democrats are increasingly pointing to the Supreme Judicial Court's decision that legalized gay marriage in Massachusetts, along with the images of gay weddings in San Francisco, as a key reason for Kerry's loss. President Bush hammered home the portrayal of Democrats as out of step with mainstream values by endorsing a federal amendment to same-sex marriage [sic] and by often reminding crowds that Kerry was from Massachusetts, a subtle code, in the eyes of some strategists.").

51. See Jesse McKinley, Several Recent Suicides Put Light on Pressures Facing Gay Teenagers, N.Y. Times, Oct. 4, 2010, at A9.

52. Bradford L. Ferguson et al., Reexamining the Nature and Role of Tax Legislative History in Light of the Changing Realities of the Process, 67 TAXES 804 (1989); Press Release, Office of Pub. Affairs, U.S. Dep't of Treasury, Donald C. Lubick Confirmed as Treasury Assistant Secretary for Tax Policy (Feb. 13, 1998), http://www.ustreas.gov/press/releases/rr2225.htm. As Paul Caron has observed, “[s]ome tax cases appear to place greater emphasis on the legislative history than on the statutory language. Judge Hall of the Tax Court has complained that '[i]t has been said, with more than a grain of truth, that judges in tax cases these days tend to consult the statute only when the legislative history is ambiguous." Paul L. Caron, Tax Myopia, Or Mamas Don't Let Your Babies Grow up to Be Tax Lawyers, 13 VA. TAx Rev. 517, 532-33 (1994) (quoting Focht v. Comm'r, 68 T.C. 223, 244 (1977) (Hall, J., dissenting)). 
tempered version of the generally accepted treatment of tax legislative history in the interpretation of the Internal Revenue Code (Code). ${ }^{53}$ Professor Paul Caron has agreed with Professor Simon, referring to the exceptionalism of the tax legislative process as a "myth." ${ }^{54}$ Though he came to no firm conclusion regarding the role that legislative history should play in the interpretation of the tax laws, Professor Caron did call for a greater integration of tax and nontax thinking regarding the role of legislative history in statutory interpretation. ${ }^{55}$

\title{
2. Statutory Interpretation
}

In a similar interpretational vein, Professor Lawrence Zelenak has considered when statutes - and, more particularly, the Code, given its "unique complexity"merit nonliteral interpretation. ${ }^{56}$ In the course of his discussion of the U.S. Supreme Court's "serious lack of consistency" 57 in adopting literal versus nonliteral interpretations of the Code, Professor Zelenak posed and then answered the following interesting question:

\begin{abstract}
Why, then, if most of the express pronouncements advocate either strict construction in favor of the taxpayer or an evenhanded approach favoring neither party, do courts in practice seem to be more willing to adopt nonliteral interpretations at the government's request than at taxpayers' request? The answer seems to be that over the decades, the courts have come to view themselves as having a special duty to act as guardians of the fisc by closing loopholes that Congress inadvertently left open. Although there is a long history of judicial willingness to protect the fisc from Congress' sloppy drafting, there is no corresponding history of judicial willingness to protect taxpayers from Congress' mistakes. The result is that the government is more likely than a taxpayer to succeed in persuading a court to adopt a nonliteral interpretation. ${ }^{58}$
\end{abstract}

More recently, Professor Mary Heen has maintained that the Court's on-again, off-again adoption of a "plain meaning" approach to statutory interpretation "poses special dangers for tax law because of the rich range of contextual and policy considerations that inform the Internal Revenue Code." $"$ Using the example of a series of cases interpreting $§ 104(a)(2)$, Professor Heen argued that

53. Karla W. Simon, Constitutional Implications of the Tax Legislative Process, 10 AM. J. TAX PoL'Y 235, 236, 237-44, 256-57 (1992).

54. Caron, supra note 52, at 531.

55. Id. at 531-54.

56. Lawrence Zelenak, Thinking About Nonliteral Interpretations of the Internal Revenue Code, 64 N.C. L. REv. 623, 630 (1986).

57. Id. at 674 .

58. $I d$. at 667 (footnote omitted).

59. Mary L. Heen, Plain Meaning, the Tax Code, and Doctrinal Incoherence, 48 Hastings L.J. 771, 771 (1997). 
inconsistent application of this approach to statutory interpretation not only risks "piecemeal and incoherent interpretations" of the statute, ${ }^{60}$ but also can have an impact on the level of deference that the Supreme Court affords to the Treasury Department's interpretation of the tax laws. ${ }^{61}$

\title{
3. Deference to Agency Interpretation
}

On this question of deference to agency interpretation (and echoing his discussion of the use of legislative history in the interpretation of the tax laws), ${ }^{62}$ Professor Caron has suggested that we put the myth of tax exceptionalism behind us and move toward a synergistic approach regarding the level of judicial deference to Treasury Department interpretations of the Code. ${ }^{63}$ Professor Kristin Hickman has likewise bemoaned the role of tax exceptionalism in discussions of the level of deference that courts should afford to Treasury regulations:

\begin{abstract}
Yet the emphasis of the existing scholarship on the uniqueness of the tax field-and the resulting complexity that this focus has added to what otherwise should be a fairly simple analysis - are emblematic of a perception of tax exceptionalism that intrudes upon much contemporary tax scholarship and jurisprudence. The view that tax is different or special creates, among other problems, a cloistering effect that too often leads practitioners, scholars, and courts considering tax issues to misconstrue or disregard otherwise interesting and relevant developments in non-tax areas, even when the questions involved are not particularly unique to tax. The ongoing debate over judicial deference toward tax regulations offers an especially frustrating example of this tax exceptionalism at work. ${ }^{64}$
\end{abstract}

More recently, in undertaking a preliminary articulation of a theory of regulatory regimes that are better explained by their history and context than by statutory language, Professor Hickman, writing with Professor Claire Hill, purposefully left the door open to the possibility that tax may actually be exceptional. ${ }^{65}$ Nonetheless, in an even more recent Internet posting, Professor Hickman concluded that the U.S. Supreme Court's decision in Mayo Foundation for

60. Id. at 812 .

61. Id. at 820 .

62. See supra text accompanying note 55 .

63. Caron, supra note 52, at 554-73; accord Christopher M. Pietruszkiewicz, Discarded Deference: Judicial Independence in Informal Agency Guidance, 74 TENN. L. REv. 1, 34 (2006) (contending that tax should not have its own deference tradition and further maintaining that other areas of administrative law could borrow from tax in developing an appropriate level of deference for informal agency guidance).

64. Kristin E. Hickman, The Need for Mead: Rejecting Tax Exceptionalism in Judicial Deference, 90 MinN. L. REV. 1537, 1541 (2006).

65. Kristin E. Hickman \& Claire A. Hill, Concepts, Categories, and Compliance in the Regulatory State, 94 MinN. L. Rev. 1151, 1157-58 (2010). 
Medical Education \& Research v. United States ${ }^{66}$ has finally sounded the death knell for tax exceptionalism with regard to deference to agency interpretations of statutes. ${ }^{67}$

\section{Comprehensive Tax Base and Tax Expenditures}

Other commentators critique those who advocate the use of a comprehensive tax base-and, implicitly, tax expenditure analysis-on tax exceptionalism grounds. Professors David Weisbach and Jacob Nussim have put this critique in colorful terms:

As far as we can tell, the only way one can make the arguments made by CTB [comprehensive tax base] advocates is to treat the tax system as separate from the rest of the government. Under this view, ensuring the efficiency and fairness of the tax system, taken alone, should be the goal of tax reformers. This produces the odd result that removing a program from the tax system and replacing it with an identical program implemented by another agency produces an efficiency and fairness gain, notwithstanding that no behavior has changed and no policy has been altered. Kyle Logue has called this view "tax-exceptionalism." Another name might be NIMBY, or Not In My Back Yard. CTB advocates want their backyard to be clean but don't seem to care about where else the trash might be put. ${ }^{68}$

The Joint Committee on Taxation (JCT) considers this critique to be leveled equally at tax expenditure analysis. ${ }^{69}$ Interpreting the critique in this way, the JCT forcefully responded to the critique, no matter its target:

There also is merit to the argument that tax expenditure analysis reflects tax "exceptionalism" - the belief that the tax system ordinarily ought not to be burdened with the sort of ad hoc political compromises reflected on the face of much spending legislation. In the view of the JCT Staff, however, that "exceptionalism" is largely justified.

66. 131 S. Ct. 704, 713-14 (2011) (declining to apply a less deferential standard of review to tax regulations than is applied to other regulations).

67. Kristin Hickman, Goodbye National Muffler! Hello Administrative Law?, TAxProf Blog (Jan. 11, 2011), http://taxprof.typepad.com/taxprof_blog/2011/01/hickman-.html.

68. David A. Weisbach \& Jacob Nussim, The Integration of Tax and Spending Programs, 113 YaLE L.J. 955, 968-69 (2004) (quoting Kyle D. Logue, If Taxpayers Can't Be Fooled, Maybe Congress Can: A Public Choice Perspective on the Tax Transition Debate, 67 U. CHI. L. Rev. 1507, 1524 (2000) (reviewing Daniel Shaviro, When Rules Change: An Economic and Political Analysis of TRANSITION RELIEF AND RETROACTIVITY (2000)).

69. Staff of Joint Comm. on Taxation, Pub. No. JCX-37-08, A Reconsideration of Tax Expenditure Analysis 35 (2008); see J. Clifton Fleming, Jr. \& Robert J. Peroni, Can Tax Expenditure Analysis Be Divorced from a Normative Tax Base?: A Critique of the "New Paradigm" and Its Denouement, 30 VA. TAX REv. 135, 174 (2010) (addressing the Joint Committee on Taxation's discussion of the tax exceptionalism argument). 
Unlike most spending programs, the tax system affects every individual and every economic transaction. The same is not true of most spending legislation. Because virtually every adult American must wrestle with the Internal Revenue Code, and because our system ultimately relies on self-assessment, it is important to reduce the compliance burden and to reinforce the view that the tax system is equitable. A taxpayer who reads 87 pages of instructions for a tax return that detail a host of special exemptions, credits, and deductions incurs substantial compliance costs (in time or money), and may come away from the experience with the belief that the tax system contains numerous special provisions that are available to others, but not to him. Both the mistakes that may result and the perception of a system riddled with special provisions undercut in an important way the success of the self-assessment system. For these reasons, the JCT Staff believes that there is merit in a presumption in favor of a tax system that is as simple and as easy to administer as possible. ${ }^{70}$

Professor Michael Graetz has come at the question of the tax exceptionalism in tax expenditures from a slightly different angle. He has referred to "our unique-[he] would insist excessive-reliance on the use of income tax expenditures as a favored mechanism to address our nation's most pressing economic and social problems" as a form of "tax policy exceptionalism."71 Graetz asserts that our excessive reliance on tax expenditures is "a luxury that we can no longer afford." 72

\section{Tax Collection}

Prior to the enactment of the collections due process provisions of the Internal Revenue Service Restructuring and Reform Act of 1998, this exceptionalism also extended to the deference given to the Internal Revenue Service in the collection of taxes. ${ }^{73}$ As Professor Leslie Book has explained:

[T]ax adjudications are not part of the administrative law landscape. Tax adjudications stand alone. This isolation is explained largely by historical practice, a practice that, with respect to the exemption of collection determinations from judicial review, stems from a belief that the government interest in tax adjudication is so vital that it warrants special treatment and unbridled discretion. ${ }^{74}$

70. Staff of Joint Comm. on Taxation, supra note 69, at 37; see Fleming \& Peroni, supra note 69, at 174 (arguing that tax expenditure analysis does not embody exceptionalism at all).

71. Michael J. Graetz, Woodworth Memorial Lecture: Tax Policy Challenges, 35 OHIO N.U. L. Rev. 1, 6 (2009).

72. Id.

73. Leslie Book, The Collection Due Process Rights: A Misstep or a Step in the Right Direction?, 41 Hous. L. REv. 1145, 1148 (2004).

74. Id. at 1174-75 (footnote omitted). 
Professor Book further explained that the case law interpreting the Due Process Clause of the Fifth Amendment was similarly marked by notions of tax exceptionalism. "Although the last few decades of the twentieth century saw an explosion of procedural developments designed to ensure that government actions did not deprive an individual of property rights or privacy rights before adequate notice and hearing, tax cases have remained outside the due process mainstream."75 Yet, as Professor Danshera Cords has observed, this tax exceptionalism has persisted even after the enactment of the collections due process provisions. ${ }^{76}$ Notwithstanding the potential for increased fairness and efficiency in the tax collections process, the Tax Court has resisted applying administrative law principles to its review of tax collections decisions (as well as claims for innocent spouse relief and interest abatement) in the same way that the federal district courts do in tax and other cases involving the review of agency decision making. ${ }^{77}$

\section{Specialized Court of Appeals}

Given the specialized nature of tax disputes and the forum shopping permitted in tax litigation, commentators - including judges, law school deans, and the Federal Courts Study Committee- have been calling for the creation of a single, specialist court to hear appeals in all tax cases since shortly after the inception of the modern federal income tax. ${ }^{78}$ Most recently, in 1998, the Commission on Structural Alternatives for the Federal Courts of Appeals suggested that, rather than creating a separate, specialized tax court of appeals, Congress could simply consolidate tax appeals in the Federal Circuit, which already hears appeals of tax cases from the Court of Federal Claims. ${ }^{79}$ To date, these calls have gone unheeded. Professor William Popkin has asserted that the crux of the opposition to creating a specialized court of tax appeals actually stems from the likelihood that the court would be exceptionally good at its job:

75. Id. at $1175-76$.

76. Danshera Cords, Administrative Law and Judicial Review of Tax Collection Decisions, 52 ST. Louis U. L.J. 429, 441 (2008).

Not all courts approaching new oversight role [sic] have done so in the same manner. The district courts apply the APA and administrative law in tax collection cases. However, the Tax Court has been slow to apply traditional abuse of discretion review and administrative law in tax collection cases. This reluctance to apply administrative law is understandable in light of the historical jurisdiction of the Tax Court, which was limited to cases that required de novo trials. In addition, tax law is often treated as separate and different from other areas of the law. Nevertheless, administrative law and its principles are applicable to most tax collection cases, and conducting a de novo trial is inconsistent with abuse of discretion review.

Id. (footnotes omitted).

77. Id. at 445-48, 474-78.

78. Caron, supra note 52, at 581-87.

79. Comm'n on Structural Alts. for the Fed. Courts of Appeals, Final Report 73-74 (1998), available at http://www.library.unt.edu/gpo/csafca/final/appstruc.pdf. 
A specialized court, confident of its expertise and of not being contradicted by another appellate court, would feel more secure than generalist courts in identifying the underlying statutory structure. The appeal to statutory structure will often (though not inevitably) undermine the more or less clear text, thereby contributing to uncertainty. Moreover, the statutory structure will often (though, again, not inevitably) limit tax avoidance-for example, by requiring transactions to have some prospect of economic profitability and by limiting the deduction of outlays with a substantial personal consumption component. In combination, the increase in uncertainty and application of anti-tax avoidance principles by a Court of Tax Appeals is likely to tilt the law more in favor of the government. ${ }^{80}$

\section{Tax Lawyers}

Tax lawyers themselves are said to feel special because of their mastery of the tax laws:

[T]he Internal Revenue Code is so difficult to understand that those who are not exceedingly familiar with the subject matter and the Code's special vocabulary will find it largely incomprehensible. Tax lawyers themselves frequently boast about their trials in coping with the complexity of the tax laws. Thus, complexity reinforces their sense of separateness and superiority to others, who want nothing to do with the statutory mess with which tax lawyers deal on a daily basis. ${ }^{81}$

The tax bar has even been referred to as a "special priesthood." 82 Indeed, despite calling attention to what he sees as a generally negative perception of tax lawyers outside of the tax bar (Tom Cruise's character in The Firm notwithstanding), ${ }^{83}$ Professor Caron closes his widely cited article, Tax Myopia, Or Mamas Don't Let Your Babies Grow up to Be Tax Lawyers, by underscoring the "special" qualities of tax lawyers:

[I]n performing their tax legislation, administration, and litigation functions, the relevant players must resist the notion that they bring nothing to the table other than their special tax expertise and background. By replacing their narrow tax lens with a panoramic perspective of the legal landscape, the tax debate will be invigorated

80. William D. Popkin, Why a Court of Tax Appeals Is So Elusive, 47 TAX Notes 1101, 1104 (1990).

81. Simon, supra note 53, at 239.

82. Caron, supra note 52 , at 526.

83. See id. at 519-31 (describing the less than positive perceptions of tax lawyers held by law students, lawyers who practice outside of the tax area, and popular culture generally); $i d$. at 589 ("Tax lawyers and professors have only themselves to blame for the popular perception that Michael Tucker, and not Tom Cruise is the prototypical tax lawyer."). 
with nontax learning while the special talents of tax lawyers and professors will generate insights useful to their nontax counterparts. ${ }^{84}$

\section{Exceptional Areas Within Tax}

Even within tax, there are some areas-for example, subchapter $\mathrm{K}$ with its rules governing the taxation of partnerships - that are more rarefied, more exceptional than others. In commenting on practitioners' negative reactions to the issuance of proposed regulations containing the partnership antiabuse rule, Tax Notes columnist Lee Sheppard stated:

The partnership bar's Weltanschaaung can be roughly summarized as follows: A partnership is a magic circle. Anything that is dropped into it becomes exempt from taxation. Forever. Any item that produces income can be allocated to a partner with losses and vice versa; the substantial economic effect rule of section 704(b) has been interpreted to mean that partners have to promise to make it up sometime before the millennium. Adherents to this view of subchapter K understand the word "flexible" to mean that you can do absolutely anything you want without incurring tax. Readers will recall that the partnership bar collectively decided to ignore the Diamond decision because they did not like the result. ${ }^{85}$

\section{Above Politics}

Finally, turning to the form of tax exceptionalism most directly relevant to this essay, many see tax as an exceptional area of the law that should be above the fray of the so-called culture wars. This form of tax exceptionalism most commonly manifests itself in hostility to critical (e.g., feminist, critical race, and queer) perspectives on the tax laws. This hostility was on full and open display in a 1998 symposium on critical tax theory in the North Carolina Law Review. ${ }^{86}$

Professor Lawrence Zelenak's lead article for that symposium began by welcoming the advent of feminist and critical race perspectives to tax because they were "long overdue." 87 Nonetheless, he immediately confessed to being "troubled that much of the work has not been carefully done." ${ }^{8}$ Professor

84. Id. at 590 (emphasis added).

85. Lee A. Sheppard, Partnerships, Consolidated Returns, and Cognitive Dissonance, 63 TAX NoteS 936, 936 (1994); see id. ("Proposed reg section 1.701-2 is a restatement of existing law, despite the partnership bar's collective belief that general principles such as the doctrine of substance over form do not apply to partnerships."); Andrea Monroe, What's in a Name: Can the Partnership Anti-Abuse Rule Really Stop Partnership Tax Abuse?, 60 CASE W. RES. L. REv. 401, 407 (2010) ("To many observers, the [partnership antiabuse rule] seemed self-evident, but the Treasury feared that subchapter K's unique combination of flexibility, complexity, and low enforcement caused some taxpayers to believe that partnerships were special and, thus, not subject to the tax system's first principles.”).

86. See Symposium, Critical Tax Theory: Criticism and Response, 76 N.C. L. Rev. 1519 (1998).

87. Lawrence Zelenak, Taking Critical Tax Theory Seriously, 76 N.C. L. Rev. 1521, 1522 (1998).

88. Id. at 1523 . 
Zelenak included among his list of common weaknesses in the literature "an overeagerness to accuse the tax laws of hostility to women or blacks," "selection bias" (i.e., choosing to focus on only those provisions in the Code that support a claim of bias), and a lack of intellectual rigor (i.e., "failure to think through proposed solutions with sufficient care"). ${ }^{89}$ Professor Zelenak closed his article by asserting that "problems of one-sidedness and incomplete analysis are more common in the critical tax literature than in the general academic tax policy literature." ${ }^{90} \mathrm{He}$ also maintained that critical tax theorists "do not approach the tax laws in a detached and disinterested frame of mind" and essentially — not to mention paradoxically — contended that the only legitimate means for finding discrimination in the Code is to stumble upon it. ${ }^{91}$ In his contribution to the symposium, Professor Steve Johnson similarly set an impossible—one might even say exclusionary - bar for engaging in legitimate critical tax scholarship by asserting that critical tax scholars can make no assertion of discrimination until every single provision in the Code has been analyzed to determine whether a group is disadvantaged on a net basis. ${ }^{92}$

Other contributors to the symposium issue were more forthright in expressing their hostility to critical tax scholarship and in ostracizing those who would sully our neutral, objective tax laws with the suggestion that they form part of a larger legal framework of subordination. Seconding Professor Zelenak's criticisms, Professor Joseph Dodge essentially referred to critical tax scholars as a group of "whiner[s]." ${ }^{33}$ Professor James Bryce bemoaned the advent of critical perspectives to the tax academic literature and proclaimed its general pointlessness. ${ }^{94}$ Professor Charles Galvin made the case for tax exceptionalism most clearly:

A tax system should be neutral in its effect on each citizen's
decisionmaking. Therefore, assuming a democratic ideal of a free
society with equal opportunity for all, the framers of tax policy should
strive for a system that is blind as to gender and color. I agree with
Professor Zelenak that any attempt to tailor the system to meet the
criticisms of feminists or racial groups rapidly becomes a nightmare of
dilemmas that are just not resolvable. One needs only to observe
lifestyles of friends, colleagues, neighbors, and relatives, and one
becomes keenly aware that to design a tax regime to meet the gender
and race considerations of each case would create a statutory maze of
confusion many times worse confounded than the current system.

89. Id. at $1523-24$.

90. Id. at 1578 .

91. Id. at $1578-79$.

92. Steve R. Johnson, Targets Missed and Targets Hit: Critical Tax Studies and Effective Tax Reform, 76 N.C. L. Rev. 1771, 1771-72 (1998).

93. Joseph M. Dodge, A Feminist Perspective on the QTIP Trust and the Unlimited Marital Deduction, 76 N.C. L. Rev. 1729, 1729 (1998).

94. James D. Bryce, A Critical Evaluation of the Tax Crits, 76 N.C. L. Rev. 1687, 1687 (1998). 
Furthermore, trade-offs between different feminist goals make simple solutions impossible. A better course is to achieve neutrality by the attainment as nearly as possible of a pure Haig-Simons comprehensive model or a pure consumed income model. ${ }^{95}$

Thus, according to Professor Galvin, tax should be deemed to exist on a higher, idealized plane where there is no racism, sexism, or other prejudice and where there is equal opportunity for all. In Professor Galvin's utopia, we can best serve all of our citizens by striving for nothing less than the theoretically perfect tax system, whether in the form of an income or a consumption tax. It is simply too much to ask our tax system to deal with mundane issues of discrimination and subordination because " $[\mathrm{t}] \mathrm{o}$ try to solve particular problems through the Internal Revenue Code would present a daunting challenge no lawmaker should or could take on." 96

The message here is that "other" areas of the law-and not tax-should be asked to grapple with and redress issues of discrimination and subordination. Tax is clearly "exceptional" and above being asked to do so.

\section{FRESH WOUNDS}

Even as we meet here today (perhaps especially so), the collision of these two others-outsiders of distinctly different sorts, one privileged and one subordinated - is carving out a point of intersection. Astonishingly, despite the surfeit of tax issues faced by (and sometimes peculiar to) LGBT individuals, ${ }^{97}$ the originary violence that is necessary to create a point where these two "others" can and do intersect has only recently gotten under way.

Evidence of the fresh wounds inflicted by this originary violence is easily found in the small amount of judicial and regulatory guidance that exists on issues specific to LGBT taxpayers. As of this writing, the federal courts have addressed the application of the tax laws to same-sex couples in just four

95. Charles O. Galvin, Taking Critical Tax Theory Seriously-A Comment, 76 N.C. L. REv. 1749, 1749 (1998).

96. Id. at 1752. Contra Anthony C. Infanti, Tax Equity, 55 Buff. L. Rev. 1191, 1240 (2008) ("It also seems disingenuous to argue that taking [critical tax] concerns into account is just too difficult, when we tolerate mind-numbing levels of complexity in areas that benefit the wealthy.").

97. See generally Patricia A. Cain, Death Taxes: A Critique from the Margin, 48 CLEv. ST. L. Rev. 677 (2000); Patricia A. Cain, Federal Tax Consequences of Civil Unions, 30 CAP. U. L. Rev. 387 (2002); Patricia A. Cain, Taxing Families Fairly, 48 Santa Clara L. Rev. 805 (2008); Adam Chase, Tax Planning for Same-Sex Couples, 72 Denv. U. L. Rev. 359 (1995); Anthony C. Infanti, Bringing Sexual Orientation and Gender Identity into the Tax Classroom, 59 J. Legal Educ. 3 (2009); Anthony C. Infanti, Deconstructing the Duty to the Tax System: Unfettering Zealous Advocacy on Behalf of Lesbian and Gay Taxpayers, 61 TAX LAW. 407 (2008); Anthony C. Infanti, Dismembering Families, in Challenging Gender Inequality in Tax Policy Making: Comparative Perspectives 159 (Kimberley Brooks et al., eds. 2011); Anthony C. Infanti, The Internal Revenue Code as Sodomy Statute, 44 SANTA Clara L. REv. 763 (2004) [hereinafter Infanti, Sodomy Statute]; Nancy J. Knauer, Heteronormativity and Federal Tax Policy, 101 W. VA. L. REv. 129 (1998). 
cases-all of which were decided between 2000 and 2010 (and two of which were brought by the same taxpayer). ${ }^{98}$ In three of these cases, the taxpayer resoundingly lost, ${ }^{99}$ but, in the fourth (and most recent) case, the taxpayer won. ${ }^{100}$ Notably, however, that recent win was not in a purely tax case; instead, tax was but one illustration of the effects of the federal Defense of Marriage Act in a broader challenge of the constitutionality of that statute. ${ }^{101}$ The federal courts have addressed the application of the tax laws to transgender individuals in just one case, ${ }^{102}$ which was decided in 2010 and was largely a win for the taxpayer-though, as more fully explained below, the victory rings hollow. ${ }^{103}$

Guidance from the Internal Revenue Service (IRS) has been similarly sparse and conflicting. Since the early 1990s, the IRS has been issuing private letter rulings regarding the tax treatment of an employer's provision of health insurance coverage for the domestic partners of its employees-though, this guidance is just as pertinent for unmarried different-sex couples as it is for same-sex couples. ${ }^{104}$ In fact, the earliest ruling addressed the tax treatment of health insurance coverage offered by a city to "nonspouse cohabitants" of its employees-a category that it created to comply with a prohibition against discrimination on the basis of marital status, not sexual or gender identity. ${ }^{105}$

More directly applicable to same-sex couples, the IRS issued guidance for California registered domestic partners after they began to be subject to the state's community property laws in $2005 .{ }^{106}$ Despite early pleas for such guidance, ${ }^{107}$ it was not until the middle of the tax-filing season in 2006 that the IRS's Office of Chief Counsel issued a memorandum in which it opined that the application of California's community property laws to same-sex couples would not be respected for federal tax purposes. ${ }^{108}$ With a change of administration,

98. Gill v. Office of Pers. Mgmt., 699 F. Supp. 2d 374 (D. Mass. 2010); Merrill v. Comm'r, 98 T.C.M. (CCH) 25 (2009); Mueller v. Comm'r, 82 T.C.M. (CCH) 764 (2001), aff'd, 90 A.F.T.R.2d (RIA) 5309 (7th Cir. 2002), cert. denied, 537 U.S. 1003 (2002); Mueller v. Comm'r, 79 T.C.M. (CCH) 1887 (2000), aff'd, 87 A.F.T.R.2d (RIA) 2052 (7th Cir. 2001), cert. denied, 534 U.S. 887 (2001). The federal government promptly appealed the decision in Gill, and that appeal is still pending at the time of this writing. Denise Lavoie, US Appeals Mass. Rulings on Gay Marriage, Boston Globe, Oct. 13, 2010, at 7.

99. Merrill, 98 T.C.M. (CCH) 25; Mueller, 82 T.C.M. (CCH) 764; Mueller, 79 T.C.M. (CCH) 1887.

100. Gill, 699 F. Supp. 2d 374.

101. Id. at 376-77, 379-83; see 1 U.S.C. $\$ 7$ (West, Westlaw through P.L. 112-90).

102. O'Donnabhain v. Comm'r, 134 T.C. 34 (2010).

103. Anthony C. Infanti, Dissecting O'Donnabhain, 126 TAX Notes 1403 (2010).

104. I.R.S. Priv. Ltr. Rul. 90-34-048 (May 29, 1990).

105. Id.; see also I.R.S. Priv. Ltr. Rul. 92-31-062 (May 7, 1992) (addressing the tax treatment of health insurance coverage provided to registered domestic partners, which include any "two adults who live together and who have agreed to be jointly responsible for basic living expenses incurred during the domestic partnership"); I.R.S. Priv. Ltr. Rul. 91-09-060 (Dec. 6, 1990) (addressing the tax treatment of health insurance coverage provided to "Principal Domestic Partners," which was "defined under the Plan as an unrelated unmarried equivalent of a husband or wife of an employee").

106. CAL. FAM. CodE $\S 297.5(a)$, (k) (West 2007).

107. See Infanti, Deconstructing the Duty to the Tax System, supra note 97, at 430-32 (describing the request for guidance).

108. I.R.S. Chief Couns. Advice 2006-08-038 (Feb. 24, 2006). 
however, came a change in position. In 2010, the IRS's Office of Chief Counsel issued a new memorandum in which it reversed course and concluded that the application of California's community property laws to same-sex couples would be respected for federal tax purposes. ${ }^{109}$ At the same time, the IRS issued a private letter ruling to an individual taxpayer generally explaining the application of this new position for income and gift tax purposes. ${ }^{110}$ The next day, the IRS's Office of Chief Counsel issued another memorandum explaining the application of this new position to a taxpayer's offer in compromise of a tax liability under $\S 7122 .{ }^{111}$

Interestingly, the IRS issued none of this guidance in a form that taxpayers are permitted to rely upon - by statute, none of this guidance is permitted to be "used or cited as precedent." "112 In her 2010 Annual Report to Congress, the National Taxpayer Advocate sharply criticized the IRS for failing to provide generally applicable, precedential guidance to same-sex couples concerning the application of the federal tax laws to them:

DOMA and various state laws regarding domestic partnerships and same-gender marriages give rise to a large number of unintended or unforeseen federal tax law ambiguities, making it possible for hundreds of thousands of taxpayers to take inconsistent positions in good faith. The National Taxpayer Advocate believes that it is a basic responsibility of government to provide taxpayers with sufficient guidance to enable them to comply with the law.

In conclusion, our preliminary recommendation is the IRS Office of Chief Counsel should publish a revenue ruling, establish adequate safe harbors, or issue other precedential guidance of general applicability. ${ }^{113}$

The IRS responded to the National Taxpayer Advocate's recommendation by rejecting the notion that it can provide useful, generally applicable guidance to same-sex couples. ${ }^{114}$ The IRS did, however, leave the door open to providing advice to taxpayers "tailored to their particular state's law." 115 But, as the National Taxpayer Advocate noted in her report, it will likely be prohibitively expensive for same-sex couples to submit private letter ruling requests to obtain

109. I.R.S. Chief Couns. Advice 2010-21-050 (May 5, 2010).

110. I.R.S. Priv. Ltr. Rul. 2010-21-048 (May 5, 2010).

111. I.R.S. Chief Couns. Advice 2010-21-049 (May 6, 2010).

112. I.R.C. $\$ 6110(\mathrm{k})(3)$ (West, Westlaw through P.L. 112-90).

113. 1 NAT'L TAXPAYer Advocate, 2010 Annual RePort to Congress, at 218 (2010), available at http://www.irs.gov/advocate/article/0,,id=233846,00.html.

114. Id

115. Id. 
confirmation regarding the application of the tax laws to their individual situations. ${ }^{116}$

From a moral perspective, President Obama's decision to cease defending the indefensible Defense of Marriage Act $^{117}$ in court is clearly a giant step in the right direction. ${ }^{118}$ It is far from clear, however, what the practical, legal effect of this order will be, especially given that the executive branch is nonetheless continuing to enforce the federal prohibition against recognizing same-sex marriages. ${ }^{119}$ If anything, this move has only further muddied the waters surrounding the application of the federal tax laws to same-sex couples. ${ }^{120}$

\section{EXAMINING A WOUND}

With the carving out of the intersection of tax with sexual and gender identity now under way, wounds are being inflicted on both the taxpayer and the tax system alike. ${ }^{121}$ In this section, I turn to examining one of the handful of judicial decisions regarding the application of the tax laws to LGBT individuals. A close reading of this case will provide us the opportunity to debride some of the wounds being inflicted by this ongoing intersectional violence while, at the same time, revealing the depth and extent of the damage inflicted on both the taxpayer and the tax system.

The case that I have chosen to focus on is O'Donnabhain v. Commissioner. ${ }^{122}$ In that case, the Tax Court considered the propriety of a transgender individual's deduction of the costs of hormone therapy, sex reassignment surgery (SRS), and breast augmentation as medical expenses under $\S 213$ of the Internal Revenue Code. ${ }^{123}$ The issue before the Tax Court was whether these expenses were for

116. Id. at 214. The National Taxpayer Advocate's focus in her report on the user fee that a taxpayer must pay in order to get the IRS to consider a private letter ruling request completely misses what, in my experience, is usually the most significant expense associated with such a request, namely the attorney's fees incurred to prepare and submit the request. See id. \& n.35 (stating that a private letter ruling request can cost "hundreds or thousands of dollars" and speaking only of a taxpayer's inability to pay the user fee).

117. 1 U.S.C. $\$ 7$ (West, Westlaw through P.L. 112-90).

118. See Charlie Savage \& Sheryl Gay Stolberg, In Turnabout, U.S. Says Marriage Act Blocks Gay Rights, N.Y. Times, Feb. 24, 2011, at A1.

119. Letter from Eric H. Holder, Jr., U.S. Attorney Gen., to John A. Boehner, Speaker of the U.S. House of Representatives (Feb. 23, 2011), available at http://www.scribd.com/doc/49404879/AttorneyGeneral-Holder-s-Letter-to-John-Boehner-on-DOMA-Appeal.

120. Anthony C. Infanti, Questions Raised by Obama Shift on DOMA, FEMINIST Law Professors (Feb. 23, 2011), http://www.feministlawprofessors.com/2011/02/follow-obama-shift-doma/.

121. See generally Anthony C. Infanti, Tax Protest, "A Homosexual," and Frivolity: A Deconstructionist Meditation, 24 ST. Louss U. PuB. L. Rev. 21 (2005) (describing Robert Mueller's tax cases and asserting that the U.S. Court of Appeals for the Seventh Circuit's labeling of Mueller's tax arguments as "frivolous" was itself frivolous, silly, and groundless).

122. 134 T.C. 34 (2010).

123. Id. at 35; see I.R.C. $\$ 213$ (West, Westlaw through P.L. 112-90). 
(deductible) "medical care"124 or instead for (nondeductible) "cosmetic surgery." ${ }^{125}$ In a reviewed decision, ${ }^{126}$ a sharply fractured Tax Court held that the taxpayer was entitled to deduct her expenses for hormone therapy and sex reassignment surgery, but not the expenses for breast augmentation. ${ }^{127}$

We will begin with a description of the factual background of this case. Next, even though it may be difficult and disturbing at times, we will turn to scrutinizing the opinions in the case. We will first bear witness as O'Donnabhain is marked with a subordinating otherness-implicitly by the Tax Court majority and then quite explicitly by the dissenting Tax Court judges. In contrast, we will witness one of the concurring Tax Court judges marking the tax laws with an exalted form of otherness in his opinion. Finally, we will reflect on all that we have witnessed in the Tax Court opinions and take stock of the damage wrought by the violent carving out of the intersection of tax with sexual and gender identity.

\section{A. BACKGROUND}

Rhiannon O'Donnabhain, the taxpayer in this case, was born male, but since childhood "had experienced extreme discomfort with her anatomical sex and felt a deep sense of inappropriateness in the gender role of that sex." ${ }^{128}$ Over time, these feelings only grew stronger. To combat them, O'Donnabhain entered the military, then worked in the male-dominated field of engineering, and finally married and had three children. ${ }^{129}$ Yet, "the[] feelings of conflict with her body intensified, resulting in regular, severe emotional pain. ... The emotional turmoil increased to such an extent that by 1996, Ms. O'Donnabhain felt like her life was unraveling." 130

124. For this purpose, "medical care" is defined as "amounts paid...for the diagnosis, cure, mitigation, treatment, or prevention of disease, or for the purpose of affecting any structure or function of the body." I.R.C. $\S 213(\mathrm{~d})(1)(\mathrm{A})$.

125. For this purpose, "cosmetic surgery" is defined as "any procedure which is directed at improving the patient's appearance and does not meaningfully promote the proper function of the body or prevent or treat illness or disease." Id. $\S 213(\mathrm{~d})(9)(\mathrm{B})$. Nonetheless, "cosmetic surgery" does not include any "surgery or procedure [that] is necessary to ameliorate a deformity arising from, or directly related to, a congenital abnormality, a personal injury resulting from an accident or trauma, or disfiguring disease." Id. $\S 213(\mathrm{~d})(9)(\mathrm{A})$.

126. "A 'reviewed' opinion is a published Tax Court opinion that was reviewed by the entire Tax Court and has precedential effect. It differs from a 'regular' opinion in that the court determined that the issue was of such significance that it required full review by all members of the court." Mark F. Sommer \& Anne D. Waters, Tax Court Memorandum Decisions-What Are They Worth?, 80 TAx Notes 384, 385 n.9 (1998).

127. O'Donnabhain, 134 T.C. at 73, 76-77.

128. Petition to Tax Court, O'Donnabhain v. Comm'r, No. 6402-06, at 3 (T.C. Apr. 3, 2006), available at http://www.glad.org/uploads/docs/cases/in-re-rhiannon-odonnabhain/odonnabhain-tax-court-petition. pdf.

129. Gay \& Lesbian Advocates \& Defenders, In re Rhiannon O’Donnabhain, http://www.glad.org/ work/cases/in-re-rhiannon-odonnabhain/ (last visited Jan. 13, 2011) [hereinafter GLAD].

130. Petition, supra note 128 , at 4 . 
After her marriage ended, O'Donnabhain's therapist diagnosed her with gender identity disorder (GID), "finding that [she] met the criteria set forth in the Diagnostic and Statistical Manual of Mental Disorders, Fourth Edition (DSMIV), and as a transsexual, in accordance with the criteria for transsexualism in the International Classification of Diseases-10."131 In both cases, the standard for treatment required individualized assessment, and the treatment could range from hormone therapy, to living in the new gender role, to surgery. ${ }^{132}$ As part of her treatment, O'Donnabhain began to take feminizing hormones in $1997 .{ }^{133} \mathrm{In}$ 2000, she "underwent surgery to feminize her facial features," legally changed her name, and began to present as female in her daily life. ${ }^{134}$ Then, in 2001 , O'Donnabhain underwent sex reassignment surgery. ${ }^{135}$ Following the surgery, "O'Donnabhain finally ha[d] a sense of comfort with her body. Feelings of conflict and pain ... disappeared as she ... succeeded in integrating her physical, mental, and emotional selves."136

The costs for the surgeries and other care relating to O'Donnabhain's transition totaled approximately $\$ 25,000 .{ }^{137}$ Given that her sex reassignment surgery was part of the medically indicated treatment for a diagnosed illness, O'Donnabhain deducted the costs of that and all related treatment on her federal income tax return as an expense for medical care. ${ }^{138}$ O'Donnabhain was then audited. The local IRS office seemed willing to allow the deduction; however, after seeking advice from the IRS Office of Chief Counsel, the local IRS office disallowed the deduction on the ground that O'Donnabhain's sex reassignment surgery and related treatment was "cosmetic surgery or other similar procedure[]." 139

As mentioned above, the question before the Tax Court was whether O'Donnabhain's position that these expenses were for medical care or the IRS's contrary assertion that they were for cosmetic surgery was correct. Ultimately, the Tax Court concluded that O'Donnabhain's expenses for hormone therapy and sex reassignment surgery were deductible because she had incurred those expenses to treat a disease (i.e., gender identity disorder). ${ }^{140}$ The Tax Court did, however, disallow the deduction for the breast augmentation surgery. Because the surgeon had not made a documented finding that O'Donnabhain's breast growth as a result of hormone therapy was insufficient to provide her with comfort in a

131. Id. at 3 .

132. Id. at 4 .

133. O'Donnabhain v. Comm'r, 134 T.C. 34,39 (2010).

134. Id. at 39-40.

135. Id. at 41 .

136. Petition, supra note 128 , at 7 .

137. GLAD, supra note 129.

138. Petition, supra note 128 , at 7.

139. I.R.S. Chief Couns. Advice 2006-03-025 (Jan. 20, 2006). Transgender individuals also face the same battle over whether their gender-confirmation-related care is medically necessary or merely cosmetic when attempting to seek reimbursement under state Medicaid programs. Dean Spade, Documenting Gender, 59 Hastings L.J. 731, 783-88 (2008).

140. O'Donnabhain, 134 T.C. at 70. 
female gender role, the court found that the surgery had not been performed in strict adherence with the accepted treatment guidelines. ${ }^{141}$ As a result, the court concluded that the breast augmentation surgery was not performed to treat gender identity disorder, but was, instead, nondeductible cosmetic surgery. ${ }^{142}$

\section{B. A SUbordinating "Otherness"}

With this factual background, we can now turn to a close reading of the opinions in O'Donnabhain v. Commissioner. We will begin with Judge Gale's lengthy opinion for the Tax Court majority. Following that, we will turn to the dissenting opinions of Judges Foley and Gustafson. As we will see, all three of these opinions mark O'Donnabhain with a distinctly subordinating form of "otherness."

\section{The Majority}

a. Losing One's Humanity. Naturally, Judge Gale began his majority opinion, which was joined by seven other Tax Court judges, ${ }^{143}$ with a recitation of the facts of O'Donnabhain's case. ${ }^{144}$ You may have already noticed that my recitation of the facts above relies, for the most part, not upon Judge Gale's opinion but on the pleadings that O'Donnabhain filed with the Tax Court and material published on her lawyers' web site. I do this not because the stories that they tell are fundamentally different, but because, in Judge Gale's opinion, we glimpse very little of O'Donnabhain's own experience of gender identity disorder, despite its being at the heart of this case. In the majority opinion, we see O'Donnabhain only from a distance, her experience - and her humanitydiminished by a court holding for her but at the same time holding her away. Descriptions of O'Donnabhain's feelings from her own perspective are peppered with phrases like "internal conflict"; ${ }^{145}$ "dissonance"; 146 "acute distress"; ${ }^{147}$

141. Id. at $72-73$.

142. Id. at 73 .

143. Id. at 77 .

144. Id. at $35-42$.

145. GLAD, supra note 129.

146. Id.

147. Id.; see also Pretrial Memorandum for Petitioner at 2, O'Donnabhain v. Comm'r, 134 T.C. 34 (2010) (No. 6402-06) ("Ms. O'Donnabhain will testify about the emotional distress and suffering she experienced because of the discordance between her anatomical birth sex and her gender identity."); id. ("significant distress"); id. at 3 ("profound distress"); id. at 5 ("serious emotional pain and distress"); id. at 16 ("severe, clinically significant distress"); $i d$. at 23 ("clinically significant distress"); Post-Trial Brief of Petitioner at 24, O'Donnabhain, 134 T.C. 34 (No. 6402-06) ("O'Donnabhain experienced significant psychological symptoms, distress and impairment as a result of her gender conflict."); $i d$. at 25 ("Ms. O'Donnabhain's distress at having male genitals became so great that at one point she took a carving knife and contemplated removing her genitals."); $i d$. at 32 ("the facial feminizing surgery performed by Reardon helped to reduce her psychological distress"); id. at 49-50 ("All of the evidence ... demonstrated the critically high levels of distress that Ms. O'Donnabhain experienced as a result of the discordance between her anatomy and her gender identity."); id. at 60 ("clinically significant distress"); 
"intense shame"; ${ }^{48}$ "inner discord"; 149 "suffering"; 150 "'feels broken' and "unwired"; ${ }^{151}$ "a lifetime of feeling utterly alone and misunderstood"; ${ }^{152}$ "extreme discomfort... and a deep sense of inappropriateness", 153 "regular, severe emotional pain"; ${ }^{154}$ "emotional turmoil"; ${ }^{155}$ and "her life was unraveling." 156 O'Donnabhain even testified that she "had thoughts of suicide. She never had a plan or intent, but had feelings that she would be better off dead because she could not find a way "to make the pain go away.""157 Following her sex reassignment surgery, O'Donnabhain expressed "a sense of comfort with her body. Feelings of conflict and pain ... disappeared as she has succeeded in integrating her physical, mental, and emotional selves." ${ }^{158}$ O'Donnabhain even went so far as to say that she was "not sure that she could have continued living without the relief she finally attained through sex reassignment surgery." ${ }^{159}$ Even the IRS noted in its brief that O'Donnabhain had testified at trial "that she would have been on drugs, been an alcoholic, or killed herself if she did not have [sex reassignment surgery]." 160 The IRS further noted that the psychologist who provided the confirming opinion in advance of O'Donnabhain's sex reassignment surgery testified that "if petitioner had not had profound distress, she would not have been an appropriate candidate for gender reassignment surgery." ${ }^{161}$ Press reports of the testimony at trial echo these same themes and describe how O’Donnabhain at times burst into tears while testifying. ${ }^{162}$

id. at 61 (same); Post-Trial Reply Brief of Petitioner at 5, O’Donnabhain, 134 T.C. 34 (No. 6402-06) (same); id. at 27 (same); id. at 47 ("debilitating distress"); id. at 48 ("overwhelming pain and distress").

148. Post-Trial Brief of Petitioner, supra note 147, at 23.

149. GLAD, supra note 129; see also Pretrial Memorandum for Petitioner, supra note 147, at 5 ("profound conflict").

150. GLAD, supra note 129.

151. Post-Trial Brief of Petitioner, supra note 147, at 24.

152. GLAD, supra note 129.

153. Petition, supra note 128 , at 3.

154. Id. at 4; see also Pretrial Memorandum for Petitioner, supra note 147, at 4 ("severe emotional pain"); Post-Trial Brief of Petitioner, supra note 147, at 26 ("she needed the hormone therapy and sex reassignment surgery "to help me end this pain that I was in"”); id. at 44-45 ("[T]he expenses at issue were to treat the pain, debilitation and symptomology that she was experiencing as a result of her GID.").

155. Petition, supra note 128, at 4; see also Pretrial Memorandum for Petitioner, supra note 147, at 5 (same).

156. Petition, supra note 8, at 4; see also Pretrial Memorandum for Petitioner, supra note 147, at 5.

157. Post-Trial Brief of Petitioner, supra note 147, at 25.

158. Petition, supra note 128 , at 7.

159. Id.

160. Opening Brief for Respondent at 16, O’Donnabhain v. Comm'r, 134 T.C. 34 (2010) (No. 6402-06).

161. Id. at 64. Of course, the IRS then went on to try to cast doubt on both the psychologist's conclusion that O'Donnabhain had suffered from profound distress and O'Donnabhain's statements and testimony that underpinned that conclusion. Id. at 64-66, 206-08.

162. Jeremiah Coder, Sex Change Operation Case Dwells on Medical Testimony and Emotion, 116 TAx Notes 348 (2007); Ethan Jacobs, Experts at Tax Trial Explain Gender Identity Disorder, EDGE (Boston, Mass.), July 26, 2007, http://www.edgeboston.com/index.php?ch=news\&sc=glbt\& $\mathrm{sc} 2=$ news \&sc $3=\& \mathrm{id}=22005$. 
In contrast, Judge Gale's opinion is nearly devoid of empathy for the pain and distress that O'Donnabhain felt prior to her surgery and the relief that she experienced following surgery. Mentions of O'Donnabhain's mental state in the recitation of the facts are few and far between. The few that are included employ far less powerful or emotive language than is used to convey O'Donnabhain's own perspective. For instance, Judge Gale speaks of O'Donnabhain's “discomfort" (or, alternatively, being "uncomfortable") with a male gender role. ${ }^{163}$ Notably, when O'Donnabhain's therapist "explained that Ms. O'Donnabhain felt "extremely uncomfortable in the male role,"” she proceeded to correct herself and say that " "uncomfortable is not a strong enough word." ${ }^{164}$ Even Judge Holmes, who wrote a separate concurring opinion that will be more fully addressed below, eschewed speaking in terms of O'Donnabhain's "discomfort" with a male gender role. ${ }^{165}$ Instead, Judge Holmes used the stronger language employed in conveying O'Donnabhain's own perspective, speaking of her "psychological distress"166 and "pathological anxiety or distress."167

Judge Gale also refers to O'Donnabhain's "anxiety" about having male genitalia. ${ }^{168}$ At one point, Judge Gale repeats the observations of O'Donnabhain's psychotherapist, who "observed that [O'Donnabhain] was sad and anxious, had very low self-esteem, had limited social interactions, and was obsessed with issues concerning the incongruence between her perceived gender and anatomical sex." 169 Judge Gale does note that "[a]fter beginning hormone therapy [O'Donnabhain] told [her psychotherapist] that she felt calmer and better emotionally and that she felt positive about her physical changes." ${ }^{170}$ And, in a footnote, Judge Gale notes that, "[i]n one instance, [O'Donnabhain] held a knife and had an urge to cut off her penis." ${ }^{171}$ Even though "clinically significant distress or impairment" has been a prerequisite for a diagnosis of gender identity disorder since $1994,{ }^{172}$ it is not until the very end of the opinion, in the two-paragraph conclusion, that Judge Gale acknowledges that "petitioner would

163. O’Donnabhain v. Comm'r, 134 T.C. 34, 35, 36 (2010).

164. Post-Trial Brief of Petitioner, supra note 147, at 24; see also Post-Trial Reply Brief of Petitioner, supra note 147, at 15 (repeating the same quotations from the psychotherapist).

165. In fact, a "focus" search of the opinion on LEXIS to find instances of variations on the word "comfort" (the exact search terms were "discomfort!," "uncomfort!," and "comfort!") revealed that only Judge Gale used these terms to refer to O'Donnabhain's condition. The only other instance was in Judge Foley's separate opinion, and it did not refer to O'Donnabhain's mental state but to the IRS's level of comfort with its own interpretation of $\$ 213$. O'Donnabhain, 134 T.C. at 109 (Foley, J., concurring and dissenting).

166. Id. at 98 (Holmes, J., concurring).

167. Id. at $99-100$.

168. Id. at 40 (majority opinion).

169. Id. at 36 .

170. Id. at 39 .

171. Id. at 40 n.17.

172. See Opening Brief for Respondent, supra note 160, at 20-22 (describing the evolution of, and current criteria for, the gender identity disorder diagnosis in the Diagnostic and Statistical Manual of Mental Disorders). 
not have undergone hormone therapy and sex reassignment surgery except in an effort to alleviate the distress and suffering attendant to GID."173

By limiting mention of O'Donnabhain's mental state-a crucial part of any diagnosis of gender identity disorder ${ }^{174}$-and downplaying that mental state when it is mentioned, Judge Gale, consciously or unconsciously, distances himself from O'Donnabhain. Judge Gale, in effect, preempts O'Donnabhain's repeated accounts of her suffering and replaces them with a more benign account of his own. Moreover, once Judge Gale turns to interpreting the law and assessing whether GID constitutes a "disease" within the meaning of $\S 213$, he pushes O'Donnabhain even further into the background. One of the factors that Judge Gale took into account in making this determination was whether there was "[a] determination by a mental health professional that the condition created a significant impairment to normal functioning, warranting treatment." ${ }^{175}$ In considering this factor, Judge Gale spoke in the most general of terms:

GID is a serious, psychologically debilitating condition. Respondent's characterization of the condition on brief as a "social construction" and "not a significant psychiatric disorder" is undermined by both of his own expert witnesses and the medical literature in evidence. All three expert witnesses agreed that, absent treatment, GID in genetic males is sometimes associated with autocastration, autopenectomy, and suicide. Respondent's expert Dr. Schmidt asserts that remaining ambiguous about gender identity "will tear you apart psychologically". Petitioner's expert Dr. Brown likewise testified that GID produces significant distress and maladaption. Psychiatric reference texts, established as reliable authority by Dr. Brown's testimony, confirm the foregoing. ${ }^{176}$

Noticeably lacking here is any reference to O'Donnabhain's own experience of gender identity disorder. This entire description relates to the generic experience of those with GID. When Judge Gale does turn to GID's effects on O'Donnabhain, which is ostensibly the point of the inquiry, he merely states, "Ms. Ellaborn [O'Donnabhain's psychotherapist] concluded that petitioner exhibited clinically significant impairment from GID, to the extent that she designated petitioner's condition as 'severe' under the DSM-IV-TR standards." 177

173. O'Donnabhain, 134 T.C. at 77. Judge Gale does use the word "distress" earlier in his opinion; however, in each instance, the word is used to describe the effects of gender identity disorder generally and not to refer to O'Donnabhain in particular. $I d$. at 36, 37 n.7, 43, 53, 59, 61, 70, 75 n.55.

174. See id. at 36 (listing the criteria for diagnosing gender identity disorder).

175. Id. at 59.

176. Id. at 61 .

177. Id. 
In all of these ways, Judge Gale marks O'Donnabhain as "other"-an otherness that has a strong flavor of subordination to it. O'Donnabhain is relegated to the background in her own case and, even when her experience is brought to the fore, it is distorted in such a way as to minimize the impact of her suffering. Litigation often requires us "to tell a partial, stylized version of [our] stories that fits what the legal system wants to hear." ${ }^{178}$ But even conformed to legal expectations, O'Donnabhain's story, as told through her pleadings and briefs, retains great emotional impact. Yet, in his majority opinion, Judge Gale manages to wring nearly all of that emotional impact from O'Donnabhain's story by displacing her own subjectivity with his own. Thus, Judge Gale's marking of O'Donnabhain as "other" not only diminishes the consequentiality of her suffering, but also implicitly diminishes her humanity-and, concomitantly, perhaps even Judge Gale's own. ${ }^{179}$

178. INFANTI, supra note 13 , at 14.

179. Emmanuel Levinas has powerfully expressed the relationship between self and other in terms of responsibility and obligation, not diminution and distancing:

No one can stay in himself; the humanity of man, subjectivity, is a responsibility for others, an extreme vulnerability. The return to self becomes interminable detour. Prior to consciousness and choice, before the creature collects himself in present and representation to make himself essence, man approaches man ....

....

.... But man must also be thought from the responsibility more ancient than the conatus of substance or interior identification, thought from the responsibility that, always calling on the outside, precisely disturbs that interiority; man must be thought from self putting himself despite himself in the place of everyone, substituted for everyone because of his very non-interchangeability; man must be thought from the condition or incondition of hostage, hostage of all the others who, precisely others, do not belong to the same genre as me, because I am responsible for them without reposing in their responsibility to me which would allow them to substitute themselves for me, because even for their responsibility I am, in the last analysis and from the beginning, responsible. It is by this supplementary responsibility that subjectivity is not the Ego [le Moi], but me [moi].

Emmanuel Levinas, Humanism of the Other 67-68 (Nidra Poller trans., 2006). These are but a few quotations culled from the text; for a fuller sense of Levinas's thoughts, please read the entire essay, Without Identity, id. at 58-69. As Richard Cohen notes in his introduction to this book:

The "otherness" of the other person arises precisely as the moral imperative that pierces the self with moral obligation, with service to the other. Indeed, the true self-hood of the self occurs precisely in and as this service. One is not called on to "love thy neighbor as oneself," according to the biblical precept, as if self-love preceded other-love and were the measure of other-love. Rather, the proper formulation of Levinas's thought is more extreme, an infinite demand never satisfied even in its fulfillment: to "love thy neighbor $i s$ oneself."

Richard A. Cohen, Humanism and Anti-humanism-Levinas, Cassirer, and Heidegger, Introduction to Emmanuel Levinas, Humanism of THE Other vii, xxvii (Nidra Poller trans., 2006). 
b. A Study in Contrast. Judge Gale's treatment of O'Donnabhain stands in stark contrast to the treatment of other taxpayers claiming medical expense deductions in novel situations. Take for instance the case of Grunwald v. Commissioner. ${ }^{180}$ In Grunwald, the taxpayers claimed a deduction for the cost of private school tuition as a medical expense. The taxpayers claimed that the private school education was therapeutic because it minimized the effects of their son Peter's handicap. ${ }^{181}$ Peter, who was blind, had been attending public school, but was placed in a classroom for handicapped children. Because the local Chicago public school system had refused to integrate blind students into classrooms with children who could see, the taxpayers were advised by a number of people to move their son to a private school so that he could be placed in a "regular school program with children who could see." ${ }^{\prime 82}$ Only one of the several private schools that the taxpayers contacted-Morgan Park Academy-was both willing and equipped to try this "experiment." ${ }^{183}$ Peter enrolled at Morgan Park and thrived there academically. ${ }^{184}$

In Grunwald, the Tax Court showed far more empathy to the taxpayers and their son than Judge Gale shows to O'Donnabhain. The Tax Court described Peter's experience at Morgan Park as follows:

The experience of participating in Morgan Park's regular academic program with normal seeing students of above average to superior intellectual abilities has resulted in Peter's having grown in confidence in his own intellectual capacities and ability to learn. Peter has acquired a capacity to function socially as well as academically, as evidenced by his conversational abilities and interest in other students. All of this has contributed to his having achieved an emotional sturdiness, a degree of social maturity and confidence to function in a sighted world which he might not have otherwise achieved. ${ }^{185}$

Though clearly sympathetic, the Tax Court ultimately denied the deduction:

Tuition and associated expenses ... were incurred for primary reasons including alleviation of the handicap of blindness, with the specific aim to minimize limitations and deprivations directly associated with the inability to see and to establish and develop specific functions of body and mind not required by those who do see-and thus to restore to the largest extent possible the ability to live a normal, useful and satisfactory life.

180. Grunwald v. Comm'r, 51 T.C. 108, 108 (1968).

181. Id. at $108,113$.

182. Id. at 109 .

183. Id.

184. Id. at 109-10.

185. Id. at 111 . 
While the petitioners' argument is novel, and indeed appealing from an equitable standpoint, we do not find it legally sound or convincing in these circumstances. ${ }^{186}$

Feeling "constrained" by the Internal Revenue Code and associated regulations, the Tax Court declined "to rewrite the statute in a new image by judicial edict," leaving that task to Congress. ${ }^{187}$ The court then went out of its way to mix statements lauding Peter and his parents in with its conclusion:

\begin{abstract}
No doubt the Morgan Park educational services paid by the petitioners were beneficial to Peter's general health and well-being and prepared him to live better in a seeing world. And no doubt the achievements accomplished are attributable in some degree to the educational atmosphere at Morgan Park, to the perseverance and ability of Peter, and to the assistance, encouragement, and selfless dedication of his parents. However, it is settled law that expenses beneficial to a person's general health and well-being, but permeated with personal considerations, do not constitute "medical care" as defined in section 213(e)(1) and the regulations promulgated thereunder. ${ }^{188}$
\end{abstract}

And this is not an isolated case. Other (non-LGBT) taxpayers have similarly encountered empathetic Tax Court judges when bringing novel claims for medical expense deductions. ${ }^{189}$

\title{
2. The Dissenters
}

The subordinating "otherness" with which O'Donnabhain is tacitly marked by Judge Gale's opinion for the Tax Court majority becomes more explicit, more concrete when we move on to consider the opinions of the judges who dissented from that decision. These judges reify O'Donnabhain's subordinating otherness in both similar and different ways.

As Judge Halpern notes in his concurring opinion, dissenting Judges Foley and Gustafson (and those who joined their opinions) go out of their way to decide against allowing O'Donnabhain to deduct expenses relating to her hormone therapy, sex reassignment surgery, and breast augmentation. ${ }^{190}$ Judge Halpern wryly observes in a footnote that:

186. Id. at 113 .

187. Id. at $115-16$.

188. Id. at 115 .

189. See Sims v. Comm'r, 39 T.C.M. (CCH) 700, 706 (1979) ("Although we are keenly and sympathetically aware of the anguish suffered by petitioners in respect of David's problems, we are compelled to find that neither Fessenden nor Chapel Hill-Chauncy Hall qualified as a 'special school'."); Randolph v. Comm'r, 67 T.C. 481 passim (1976) (describing at length the plight of a couple with severe chemical allergies and allowing a deduction for the increased costs incurred by them to purchase only organic foods).

190. O’Donnabhain v. Comm'r, 134 T.C. 34, 78 (2010) (Halpern, J., concurring). 
Clearly the issues before us are important to respondent [Commissioner of the IRS]. His opening brief is 209 pages long, and his answering brief is 72 pages long. Between them, the two briefs show a total of eight attorneys assisting the Chief Counsel, in whose name the briefs are filed. I assume that respondent made all the arguments that he thought persuasive. ${ }^{191}$

And this in a case where the asserted tax deficiency was a paltry ${ }^{192} \$ 5,679$ and the issue was straightforward. ${ }^{193}$ Yet, notwithstanding an expenditure of government time and effort in briefing this case that seems out of all proportion to the revenue at stake, both Judge Foley and Judge Gustafson take the time to develop additional arguments against O'Donnabhain's position.

There is some debate about whether it is appropriate for judges to raise and consider arguments that the parties to the lawsuit did not raise themselves. ${ }^{194}$ Even were we to accept that it is appropriate for judges "to reach the best conclusion (to 'get it right') in each case" because judges determine the law not only for the parties before them but also for the public, ${ }^{195}$ the additional arguments raised and considered by the dissenters in this case seem superfluous. Given the exhaustive (and exhausting) briefing of this case as well as the number of attorneys and expert witnesses involved, it seems highly unlikely that the parties missed the best or most valid arguments for resolving the issue presented to the court. Moreover, the dissenters raise arguments that are spurious and, in the case of Judge Gustafson's dissent, motivated by obvious animus toward O’Donnabhain.

191. Id. at $78 \mathrm{n} .1$.

192. At least from the government's perspective.

193. Opening Brief for Respondent, supra note 160, at 1, 2; Post-Trial Brief of Petitioner, supra note 147 , at 1 . Not only is the cost in lost revenue small in this individual case, but it is small overall. Given the tiny fraction of individuals within the transgender community who seek sex reassignment surgery each year, a decision in O'Donnabhain's favor hardly results in throwing the doors to the treasury wide open:

A . . . study in the DSM IV estimates that one in 10,000 people seek sex reassignment surgery each year in the United States. Within the transgender community, surgery is not common. Approximately $1 \%-3 \%$ of all transgender individuals actually undergo genital reassignment surgery. This figure reflects the high cost of surgery, but also the fact that many groups within the transgender community do not desire genital reassignment surgery. For example, expressing gender through hairstyle or clothing is sufficient for some transgender people. Alternatively, some transgender people are ineligible for surgery because they have other medical issues.

Travis Cox, Comment, Medically Necessary Treatments for Transgender Prisoners and the Misguided Law in Wisconsin, 24 WIS. J.L. GENDER \& Soc'Y 341, 360-61 (2009) (footnotes omitted); see also Helen G. Berrigan, Transsexual Marriage: A Trans-Atlantic Judicial Dialogue, 12 LAW \& SEXUALITY 87, 88 n.6 (2003) ("Information from some European nations indicate [sic] that roughly one out of 30,000 adult males and one out of 100,000 adult females seek sex-reassignment surgery.").

194. See generally Sarah M.R. Cravens, Involved Appellate Judging, 88 MARQ. L. Rev. 251 (2004) (considering the question of when, if ever, it is appropriate for appellate judges to consider arguments not raised by the parties).

195. Id. at 294-95. 
a. Judge Foley's Opinion. When addressing these additional arguments, which Judge Gale flatly ignores in his opinion for the majority, ${ }^{196}$ Judge Halpern reserves his harshest words for Judge Foley's opinion. In that opinion, which was joined by four other judges (including Judge Gustafson), Judge Foley openly accuses Judge Gale and the majority of judicial activism when they interpret $\S 213$ in O'Donnabhain's favor: "In allowing deductions relating to petitioner's expenses, the majority has performed, on congressional intent, interpretive surgery even more extensive than the surgical procedures at issue-and respondent has dutifully assisted. This judicial transformation of section 213(d)(9) is more than cosmetic." 197 Circumventing the entire debate about judicial deference to agency interpretation of statutes, Judge Foley concluded his opinion by chastising the IRS for not adopting his preferred, ostensibly plain language interpretation of $\S 213$ in a section titled "Congressional Activity, Rather than Respondent's Litigation Laxity, Should Determine Deductibility." ${ }^{198}$ But Judge Halpern turns Judge Foley's own accusations against him when he observes that Judge Foley's arguments "simply disregard[] the rules of grammar and logic in favor of a part of the legislative history that is silent as to the interpretative question he fashions." ${ }^{199}$ A clearer indictment of Judge Foley's opinion as the work of an activist judge - one who has contorted both law and language to rule against O'Donnabhain—could hardly be penned.

b. Judge Gustafson's Opinion. Yet, Judge Gustafson's opinion, which is joined by four other judges (including Judge Foley), is even more troubling because it demonstrates a thinly veiled animus toward O'Donnabhain and an inability to leave personal prejudice behind in deciding the case presented to the court. Judge Gustafson begins his opinion by making it clear that he has only grudgingly acquiesced in using feminine personal and possessive pronouns to refer to O'Donnabhain: "Consistent with petitioner's preference, I use feminine pronouns to refer to petitioner in her post-SRS state. However, this convention does not reflect a conclusion that petitioner's sex has changed from male to female." ${ }^{200}$ As I have observed elsewhere, "[t]his latter sentence is little more than an unseemly, gratuitous jibe," ${ }^{201}$ especially when it is read together with the immediately preceding sentence in the text of the opinion. In that sentence, Judge Gustafson states, "After these procedures, petitioner 'passed' as female and became happier." ${ }^{202}$ It is also worth underscoring that Judge Gustafson refers to

196. O'Donnabhain, 134 T.C. at 78 (Halpern, J., concurring) ("My colleagues raise arguments in support of respondent that he did not make. Because they are not addressed by the majority, I use this opportunity to address them." (footnote omitted)).

197. Id. at 104 (Foley, J., concurring and dissenting).

198. Id. at 108-09.

199. Id. at 85 (Halpern, J., concurring).

200. Id. at 109 n.2 (Gustafson, J., concurring and dissenting).

201. Infanti, supra note 103, at 1405.

202. O'Donnabhain, 134 T.C. at 109 (Gustafson, J., concurring and dissenting). 
O'Donnabhain in the masculine whenever the reference relates to a time before she underwent surgery. ${ }^{203}$ Judge Gustafson therefore clearly disregards O'Donnabhain's self-perception regarding her gender and keys his pronouns to her physical appearance, regardless of its dissonance with that self-perception.

Judge Gustafson also conveys a sympathy for the position that sex reassignment surgery is unethical and should not be performed by doctors at all. He begins his opinion by describing O'Donnabhain as "the father of three children from a marriage that lasted 20 years. Although physically healthy, he was unhappy with his male anatomy and became profoundly so, to the point of contemplating self-mutilation." "204 After describing the medical procedures that O'Donnabhain underwent and stating the general issue to be decided by the Tax Court, Judge Gustafson clarifies what is not at issue in the case:

The surgical procedures involved in this case are startling, and to avoid distraction from the actual issues, it is expedient to affirm what is not at issue here: Neither the tax collector nor the Tax Court sits as a board of medical review, as if it were reconsidering, validating, or overruling the medical profession's judgments about what medical care is appropriate or effective for what medical conditions. Likewise, neither the tax collector nor the Tax Court passes judgment on the ethics of legal medical procedures, since otherwise deductible medical expenses are not rendered non-deductible on ethical grounds. See, e.g., Rev. Rul. 73-201, 1973-1 C.B. 140 (cost of legal abortion held deductible under section 213). ${ }^{205}$

By referring to the procedures as "startling," essentially likening sex reassignment surgery to the hot-button issue of abortion, ${ }^{206}$ and-in keeping with his reference to the disputed ethicality of abortion - then going on to note a minority

203. E.g., id.

204. Id.

205. Id. at 110 .

206. Federal funding of abortion has been a source of great contention in the ongoing debate over reforming our health care system. See, e.g., Editorial, The New Abortion Wars: A Highly Intrusive Federal Bill, N.Y. TIMES, Jan. 30, 2011, at WK7. Indeed, a bill introduced in the U.S. House of Representatives would disallow a deduction under I.R.C. $\S 213$ for "amounts paid or incurred for an abortion or for a health benefits plan that includes coverage of abortion." No Taxpayer Funding for Abortion Act, H.R. 3, 112th Cong. $§ 2$ (2011). As its sponsor makes clear, this bill is high on the agenda of the Republican House majority:

"The fact that it is designated as HR 3 speaks volumes the prioritization by Speaker (John) Boehner and Majority Leader (Eric) Cantor," said Rep. Chris Smith, R-N.J. Smith is the key sponsor of the bill to write the Hyde language into permanent law. (House leaders give the first handful of bill numbers to measures they want to highlight as legislative priorities.)

Julie Rovner, GOP Takes Latest Abortion Fight to the Tax Code, Shots: NPR's Health Blog (Feb. 9, 2011, 12:01 AM), http://www.npr.org/blogs/health/2011/02/09/133596340/gop-takes-latest-abortion-fightto-the-tax-code?ps=sh_sthdl. 
view in the psychiatric community that sex reassignment surgery is unethical, ${ }^{207}$ Judge Gustafson squarely places a frame of moral revulsion around his opinion. Judge Gustafson then spends the remainder of his opinion painting a rather repulsive picture to fill this frame. He begins by turning to the language of $\S 213$, which defines nondeductible "cosmetic surgery" to include "any procedure which is directed at improving the patient's appearance and does not meaningfully promote the proper function of the body or prevent or treat illness or disease." ${ }^{208}$ In refuting Judge Goeke's assertion in his concurring opinion that O'Donnabhain's sex reassignment surgery was not cosmetic surgery because it did not improve her appearance but was instead functional, Judge Gustafson managed not only to reaffirm his revulsion toward O'Donnabhain but also to essentialize women as little more than reproductive vessels:

\begin{abstract}
[T] here is no basis for the conclusion that SRS [sex reassignment surgery] is "functional". Petitioner's SRS did not involve any attempt to confer female reproductive function. No one undertaking to "promote" sexual "function" would perform a penectomy and a castration on a healthy male body. On the contrary, SRS drastically terminates a male patient's functioning sexuality. SRS did not change petitioner into a "function[ing]" female, but removed his salient male characteristics and attempted to make him resemble a woman-i.e., by petitioner's lights, to "improve[ ] the patient's appearance". The majority shows that the SRS surgeon does try to salvage, as much as possible, some possibility for subsequent sexual response, and observes that SRS "alter[s] appearance (and, to some degree, function)"; but the majority makes no finding that petitioner proved that any identifiable portion of the SRS expense can be allocated to restoration of "function". On our record, petitioner's SRS must be said to have been directed at improving appearance rather than promoting function, and it is therefore within the definition of "cosmetic surgery". ${ }^{209}$
\end{abstract}

Things grow even uglier when Judge Gustafson begins to discuss whether O'Donnabhain's sex reassignment surgery constitutes "treatment" for gender identity disorder. Judge Gustafson first partakes of Judge Foley's contortion of language when he blithely draws a distinction between the words "treat" and "mitigate" that is directly contrary to the definitions that he chooses to employ. ${ }^{210}$

207. O'Donnabhain, 134 T.C. at 110 n.3 (Gustafson, J., concurring and dissenting).

208. I.R.C. $§ 213(d)(9)(B)$ (West, Westlaw through P.L. 112-90).

209. O'Donnabhain, 134 T.C. at 112 n.4 (Gustafson, J., concurring and dissenting) (emphasis and citations omitted).

210. Id. at 116-17. Judge Gustafson accepted the definition of "treat" as "to deal with (a disease, patient, etc.) in order to relieve or cure." 'Id. at 116 (quoting WEBSTER's NEW UNIVERSAL UNABRIDGED DiCTIONARY 2015 (2003)). He then indicated that the same dictionary "observes that the "central meaning [of 'mitigate'] is 'to lessen' or 'make less severe."' Id. (quoting WEBSTER's NEW UNIVERSAL UnABRIDGED DiCTIONARY 1233 (2003)). Ignoring the plain language of these definitions, Judge Gustafson concludes 
He then displaces O'Donnabhain's own sense of self-as well as the considered judgment of her doctors - and substitutes it with his own preconceived notion ${ }^{211}$ that O'Donnabhain is suffering from a "delusion"212 and that sex reassignment surgery is, in no sense, a treatment for her mental disorder.

Because the force of Judge Gustafson's disdain for O'Donnabhain (and the transgender community more broadly) would be diminished in any attempt to recapitulate his polemic, I will now quote from Judge Gustafson's opinion at length to give you a sense of its true flavor:

For the GID patient there is a dissonance between, on the one hand, his male body (i.e., his male facial appearance, his male body hair, his male body shape, his male genitalia, his male endocrinology, and the $\mathrm{Y}$ chromosomes in the cells of his body) and, on the other hand, his perception of himself as female. The male body conflicts with the female self-perception and produces extreme stress, anxiety, and unhappiness.

One could analyze the GID patient's problem in one of two ways: (1) His anatomical maleness is normative, and his perceived femaleness is the problem. Or (2) his perceived femaleness is normative, and his anatomical maleness is the problem. If one assumes option 2, then one could say that SRS does "treat" his GID by bringing his problematic male body into simulated conformity (as much as is possible) with his authentic female mind.

However, the medical consensus as described in the record of this case is in stark opposition to the latter characterization and can be reconciled only with option 1: Petitioner's male body was healthy, and his mind was disordered in its female self perception. GID is in the jurisdiction of the psychiatric profession-the doctors of the mindand is listed in that profession's definitive catalog of "Mental Disorders". When a patient presents with a healthy male body and a professed subjective sense of being female, the medical profession does not treat his body as an anomaly, as if it were infected by the disease of an alien maleness. Rather, his male body is taken as a given, and the patient becomes a psychiatric patient because of his disordered

that " "treatment' addresses underlying causes and 'mitigation' lessens effects." Id. at 117. When considering the definition of the word "treat," Judge Gustafson focuses only on the words immediately preceding the parenthetical — that is, "to deal with" — and wholly ignores that this "dealing with" a disease was for the purpose of either "reliev[ing]" or "cur[ing]" the disease. When the full definition is considered, the words "treat" and "mitigate" overlap because, in the context of a disease, they both aim, at least in part, at relieving or lessening the effects of the disease. Judge Halpern hints at the dubiousness of Judge Gustafsons's distinction between the words "treat" and "mitigate," but accepts the distinction for the sake of argument because he believes that Judge Gustafson reached the wrong conclusion even when misconstruing these definitions. Id. at 78 (Halpern, J., concurring).

211. As Judge Halpern keenly observes, "Judge Gustafson cannot fathom that someone with a healthy male body who believes he is female is not sick of mind." Id. at 78 (Halpern, J., concurring).

212. Id. at 117 n.9 (Gustafson, J., concurring and dissenting). 
feeling that he is female. The majority concludes that GID is a "serious mental disorder"-i.e., a disease in petitioner's mind-and I accept that conclusion.

A procedure that changes the patient's healthy male body (in fact, that disables his healthy male body) and leaves his mind unchanged (i.e., with the continuing misperception that he is female) has not treated his mental disease. On the contrary, that procedure has given up on the mental disease, has capitulated to the mental disease, has arguably even changed sides and joined forces with the mental disease. In any event, the procedure did not (in the words of Havey $v$. Commissioner) "bear directly on the $* * *$ condition in question", did not "deal with" the disease (per Webster's), did not "treat" the mental disease that the therapist diagnosed. Rather, the procedure changed only petitioner's healthy body and undertook to "mitigat[e]" the effects of the mental disease.

Even if SRS is medically indicated for the GID patient-even if SRS is the best that medicine can do for him-it is an otherwise cosmetic procedure that does not "treat" the mental disease. Sex reassignment surgery is therefore within "cosmetic surgery or other similar procedures" under section 213(d)(9)(A), and the expense that petitioner incurred for that surgery is not deductible under section 213(a). ${ }^{213}$

Taken together, as they must be ${ }^{214}$ Judge Foley's and Judge Gustafson's opinions reify the majority's marking of O'Donnabhain as "other." Although Judge Gale's distancing himself from O'Donnabhain and concomitant diminishing of her humanity must be sussed out from a comparison of his language with O'Donnabhain's own, the very surface of Judge Foley's and Judge Gustafson's opinions is indelibly marked with pocks of subordination. Both judges contort law and language and advance arguments not put forward by the IRS - in a case that appears to have been staffed and briefed out of all proportion to the revenue at stake - all to serve their own reactionary end of denying a deduction for expenses related to sex reassignment surgery. Judge Gustafson then crystallizes the subordinating effects of these arguments by expressing sympathy for the position that sex reassignment surgery is unethical, labeling O'Donnabhain delusional, disregarding O'Donnabhain's sense of self, and expressing his own judgment that sex reassignment surgery in no way treats GID. Contrary to the opinion of medical professionals, Judge Gustafson implies that the only real treatment for O'Donnabhain was psychotherapy to address her delusion regarding her gender identity. Judge Gustafson's paternalistic tone-a tone that clearly signals his feeling that he knows better than both O'Donnabhain and the medical

213. Id. at 121-22 (citations omitted).

214. All five dissenters signed on to, and explicitly agreed with, both of these opinions. In other words, Judge Foley's opinion was joined by Judges Wells, Vasquez, Kroupa, and Gustafson. Id. at 109 (Foley, J., concurring and dissenting). Judge Gustafson's opinion was joined by Judges Wells, Vasquez, Kroupa, and Foley. Id. at 122 (Gustafson, J., concurring and dissenting). 
professionals who treated her-could not render any clearer his condescension toward O'Donnabhain as well as, more generally, the transgender community and the community of medical professionals who treat GID.

At one point in his concurring opinion, to which we turn in the next section, Judge Holmes chides the IRS for making the argument that the suffering of people with gender identity disorder is primarily inflicted by an intolerant society. ${ }^{215}$ Of this argument, Judge Holmes says, "It is not effective advocacy to denigrate the people whose government one is representing." 16 The same reproof applies equally to the dissenting judges, who spill much ink denigrating a taxpayer who has come before-and whose taxes fund the operation of - the court on which they sit.

\section{An Exalted "Otherness"}

As we should by now expect, tax is itself marked as "other" by the O'Donnabhain court. And, as we should further expect, this is not an "otherness" flavored with subordination, as O'Donnabhain's is. Rather, it is an "otherness" that presents tax as being elevated, above the fray, somehow on a higher plane.

This is most apparent in Judge Holmes's concurring opinion. Judge Holmes agrees with the result reached by the majority, but takes Judge Gale to task for including a section in his opinion explaining that sex reassignment surgery "is the proper treatment-indeed, medically necessary at least in 'severe' cases-for GID." ${ }^{17}$ Judge Holmes feels that this discussion is not only unnecessary, but also "drafts our Court into culture wars in which tax lawyers have heretofore claimed noncombatant status." 218 Thus, in Judge Holmes's eyes, tax is no party to social and cultural debates; it is somehow above this level of political discourse. In making this statement, Judge Holmes blatantly ignores how much a part of our culture-and of these cultural debates-tax law really is. ${ }^{219}$ The growing critical tax literature highlights the many ways in which the tax laws are used to reinforce

215. Id. at 91 n.3 (Holmes, J., concurring).

216. $I d$.

217. Id. at 85 .

218. $I d$.

219.

Some commentators have taken critical tax theorists to task for being too willing to find discrimination in the Code. This response can only be expected from adherents of the traditional tax narrative, because critical analysis undermines the basic tenets of their view of the tax system. The problem, however, with such blind adherence to the traditional tax narrative is that it runs counter to the mirror theory of the relationship between law and society, which is well-accepted among comparative law scholars. This theory, which might be described more accurately as a group of theories articulated with differing levels of strength, posits that law is a reflection of the society that created it. This theory leaves me with a question for adherents of the traditional tax narrative: If the law (including tax law) is a reflection of the society that created it, why wouldn't the law reflect the biases and prejudices of that society just as well as its core values and goals?

Infanti, Sodomy Statute, supra note 97, at 779 n.29 (citations omitted). 
majoritarian norms and form an integral part of the complex web of subordination in American society along lines of race, ethnicity, gender, sexual orientation, marital status, and disability (to name a few). ${ }^{220}$

Judge Holmes underscores his (and, by extension, the tax laws') discomfort with O'Donnabhain (and, by extension, all transgender individuals) when he then speaks of the "crash course on transsexualism that this case has forced on us."221 Tax lawyers are sometimes said to be the last generalists. ${ }^{222}$ As a practical matter, this means that tax lawyers (and Tax Court judges) are routinely required to take a "crash course" in all sorts of subjects-from financial instruments and hedging transactions $\mathrm{s}^{223}$ to the business of professional sports ${ }^{224}$ to the regulation of gambling $^{225}$ to the nature of religious beliefs and practices ${ }^{226}$ - merely to be equipped with the basic background knowledge necessary to identify and apply the relevant tax laws to the facts presented. ${ }^{227}$ Notwithstanding the recurring need to undergo crash courses in all sorts of nontax subjects, a search of all Tax Court cases revealed that this is the first time that any Tax Court (or, for that matter, Board of Tax Appeals) judge has ever used the phrase "crash course" in an opinion. ${ }^{228}$ By lamenting the need to do something in this case that Tax Court judges must do in so many others, Judge Holmes implies that tax law (and the Tax Court) is happy to grapple with the intricacies of the lives of those in the "mainstream" or "majority," but should be above having to grapple with the concerns of those who are subordinated, only deigning to learn about and address their lives when absolutely forced to do so.

220. See generally Critical TAX Theory: An Introduction (Anthony C. Infanti \& Bridget J. Crawford eds., 2009) (collecting excerpts from critical tax pieces touching on all of these lines of subordination). To Judge Holmes's credit, after the Tax Court issued its decision in O'Donnabhain and I penned a short piece sharply criticizing (among other things) Judge Holmes's unfamiliarity with critical tax theory, see Infanti, supra note 103, he wrote me to ask if I would donate a copy of Critical Tax Theory: An Introduction to the Tax Court library. He promised to read it, if I were to donate a copy (which I did).

221. O'Donnabhain, 134 T.C. at 86 (Holmes, J., concurring).

222. E.g., M. Bernard Aidinoff, Tax Lawyering: A Changing Profession, 46 TAX LaW. 665 passim (1993); Victor Fleischer, "If You Can Do Tax, You Can Do Anything," Conglomerate Blog (Nov. 19, 2006), http://www.theconglomerate.org/2006/11/if_you_can_do_t.html.

223. Corn Prods. Ref. Co. v. Comm'r, 350 U.S. 46 (1955).

224. First Nw. Indus. of Am., Inc. v. Comm'r, 649 F.2d 707 (9th Cir. 1981).

225. Zarin v. Comm'r, 916 F.2d 110 (3d Cir. 1990).

226. Hernandez v. Comm'r, 490 U.S. 680 (1989); Fred W. Amend Co. v. Comm'r, 454 F.2d 399 (7th Cir. 1971).

227. To underscore how common these crash courses are, I was able to develop this list in a few moments simply by flipping through the textbook that I use to teach the basic federal income tax course. Joel S. Newman, Federal Income Taxation: Cases, Problems, and Materials 39, 47, 153, 319, 541 (4th ed. 2008). In fact, I find that one of the greatest sources of difficulty for students in studying tax is not necessarily the tax rules being studied, but the need to understand the underlying transaction to which the rules are being applied.

228. On January 20, 2011, I performed this search in the TCTM database on LEXIS, which covers U.S. Tax Court cases and memorandum decisions as well as Board of Tax Appeals decisions. The query was simply for instances of the phrase "crash course," and it only returned one result-O'Donnabhain v. Comm'r, 134 T.C. 34 (2010). 
Judge Holmes reasserts tax's privileged status when he moves to the heart of his argument that avoiding the question of medical necessity would have been the "sounder course." 229 Judge Holmes contends that " medically necessary" is a loaded phrase," because "[c]onstruing it puts us squarely, and unnecessarily, in the middle of a serious fight within the relevant scientific community, and the larger battle among those who are deeply concerned with the proper response to transsexual persons' desires for extensive and expensive surgeries." ${ }^{230}$ Ostensibly to give context to Judge Gale's discussion of GID in his opinion for the majority, Judge Holmes outlines four different possible approaches to "transsexualism": (1) treating it as a delusion, (2) focusing on the perception of the individual that there is a mismatch between her gender and her biological sex, (3) treating it as a form of erotic attachment, and (4) treating it as a birth defect. ${ }^{231}$ Judge Holmes acknowledges that the fourth view is the one that is "currently predominant ... among those professionally involved in the field." ${ }^{232}$ Nonetheless, Judge Holmes criticizes the medical standards used by the professionals who treated O'Donnabhain on the ground that they do not necessarily reflect "the consensus of the entire medical community."233 In providing this "context," Judge Holmes implicitly gives credence to the alternative approaches_including that embraced by Judge Gustafson of treating O'Donnabhain as delusional—and holds the medical standards applied by the professionals in this case to an unreasonably high threshold of acceptance. ${ }^{234}$ Moreover, Judge Holmes argues that the organization that promulgated these standards is not only a medical but also an advocacy organization and that it has "medicaliz[ed] its advocacy.",235

Against this background, Judge Holmes views the notion that sex reassignment surgery is "the best_-and perhaps the only_treatment for GID" as little more than a political campaign. ${ }^{236}$ It has been "extensively promoted"; it has

229. O’Donnabhain, 134 T.C. at 92 (Holmes, J., concurring).

230. Id.

231. $I d$. at $86-88$.

232. Id. at 87 .

233. Id. at 88 .

234. $C f$. Restatement (SeCOND) OF TorTs $§ 299$ A (1965) (in determining whether a professional has been negligent, judging her by the level of "skill and knowledge normally possessed by members of that profession or trade in good standing in similar communities"); id. cmt. f ("Where there are different schools of thought in a profession, or different methods are followed by different groups engaged in a trade, the actor is to be judged by the professional standards of the group to which he belongs. The law cannot undertake to decide technical questions of proper practice over which experts reasonably disagree, or to declare that those who do not accept particular controversial doctrines are necessarily negligent in failing to do so."); $i d$. cmt. g ("Allowance must be made also for the type of community in which the actor carries on his practice... Such allowance for the type of community is most frequently made in professions or trades where there is a considerable degree of variation in the skill and knowledge possessed by those practicing it in different localities. It has commonly been made in the cases of physicians or surgeons, because of the difference in the medical skill commonly found in different parts of the United States, or in different types of communities.").

235. O'Donnabhain, 134 T.C. at 90 (Holmes, J., concurring).

236. Id. at 92 . 
become a "cause"; its purpose is to paint those who deny insurance coverage for sex reassignment surgery as engaging in discrimination or unjustly deferring to stereotypes. ${ }^{237}$ Judge Holmes, in effect, accuses Judge Gale and the majority of dragging tax from its exalted plane of existence down into the muddy trenches of these cultural battles. ${ }^{238}$ Implicitly, Judge Holmes once again reaffirms that tax law's rightful place should be above the fray of the political campaigns waged as part of the broader "culture war."

Ironically, what lends tax law the air that it is (or, at the very least, ought to be) above the political fray is its liaison with the field of economics and the air of scientificity that this liaison lends to tax law. ${ }^{239}$ In Judge Holmes's eyes, medical science is obviously not above the political fray here, as he sees medical organizations engaging in advocacy and medicine being used to further political ends. But, Judge Holmes apparently sees tax law as residing on a plane above even the science from which its exceptionalism in part stems, as he seems to feel that tax law should not be mired in the same politicization to which science is so obviously susceptible.

\section{No Escape Unscathed}

O'Donnabhain's Tax Court case is thus both a microcosm of the "otherness" of both the LGBT community and of the tax laws as well as the site of their collision. As we will now explore, neither of these "others"- one exalted and one subordinated-emerges from this intersectional collision unscathed. In this sense, simultaneously despite and because of their otherness, both the LGBT community and the tax system are one and the same. ${ }^{240}$

237. $I d$.

238. Of course, as the previous section makes abundantly clear, it was the dissenters, rather than the court's majority, who dragged tax from its place above the fray and brought it into the crossfire of the so-called culture war.

239. See, e.g., Miranda Stewart, Global Trajectories of Tax Reform: The Discourse of Tax Reform in Developing and Transition Countries, 44 HARV. INT'L L.J. 139, 172 (2003) ("Tax reform discourse is primarily an economic discourse, and it claims to be scientific largely through its affiliation with economics and public finance theory. The technical nature of tax reform discourse gives it added authority through a claim to a 'superior form' of knowledge."); Reuven S. Avi-Yonah, Tax Stories and Tax Histories: Is There a Role for History in Shaping Tax Law?, 101 Mich. L. Rev. 2227, 2234 (2003) (reviewing Tax Stories: An In-Depth Look at Ten Leading Federal Income Tax Cases (Paul L. Caron ed., 2003)) ("If you listen to many academic expositions of tax law, you might think that taxation is grounded in the exact sciences (or at least in economics), and therefore that it progresses over time-as scientific knowledge improves, tax law gets better."); id. at 2237 ("One view of tax scholarship in the last three decades is that it has tried mightily to distance itself from politics and present itself as a neutral science that is based on economic or philosophical principles and hence improves over time.").

240. DeRrida, GIFT OF DEATH supra note 5, at 87 ("For the game between these two unique "every others,' like the same 'every other,' opens the space and introduces the hope of salvation, the economy of 'saving oneself' that we shall shortly discuss. Linking alterity to singularity or to what one could call the universal exception or the law of the exception (tout autre est tout autre signifies that every other is singular, that every one is singularity, which also means that every one is each one, a proposition that seals the contract between universality and the exception of singularity), this play of words seems to 


\section{Damage to O'Donnabhain}

On the surface, O'Donnabhain emerges victorious, but only partially. She was permitted to deduct the expenses related to her sex reassignment surgery and her hormone therapy, but the deduction for her breast augmentation surgery was denied. The denial of the latter deduction was ostensibly based on her surgeon's failure to document the need for the surgery in accordance with the prevailing treatment standard. Yet, as Judge Halpern observes, Judge Gale's majority opinion did not treat this as a mere failure of proof, but instead made it sound as if her breast augmentation surgery were a sop to her vanity rather than a necessary part of reassigning her gender. ${ }^{241}$ Relying on suggestions in the contemporaneous documentation that suggested that O'Donnabhain's breasts-“" "approximately B cup breasts with a very nice shape" - -were within "a normal range of appearance," Judge Gale concluded that the breast augmentation surgery fell within the statutory definition of nondeductible cosmetic surgery because it "merely improved her appearance." 242 This only puts further distance between Judge Gale and O'Donnabhain and lends the majority's split decision a Solomonic air no doubt intended to detract from the dissenters' accusations of judicial activism.

Delving more deeply, it becomes clear that the price of even this partial victory is quite dear. The Tax Court majority holds O'Donnabhain at arm's length even while nominally siding with her. Perhaps Judge Gale keeps his distance from O'Donnabhain in an effort to rob the dissenters' accusations of judicial activism of their force. That may explain why Judge Gale largely speaks of GID in abstract terms rather than grounding his discussion in the experience of the taxpayer who has claimed expenses for the treatment of GID. That does not, however, explain why, on the few occasions when Judge Gale does address O'Donnabhain's experience of GID, he downplays that experience by avoiding the language employed by O'Donnabhain and her doctors and replacing it with his own account that minimizes her suffering. Whatever the reason for this distancing and displacement, O'Donnabhain's victory comes at the cost of debasing her humanity.

The dissenters multiply these costs by openly denigrating O'Donnabhain. They grudgingly refer to her in the feminine, label her deluded, and imply that she would have been better served undergoing psychotherapy to address her delusion rather than undergoing surgery that mutilated her perfectly healthy male body. Thus, the dissenters also displace O'Donnabhain's subjectivity with their own-but this time, rather than merely recapitulating her experience in a diminished form, they replace it outright with their own preconceived notions

contain the very possibility of a secret that hides and reveals itself at the same time within a single sentence and, more than that, within a single language.").

241. O'Donnabhain, 134 T.C. at 77-78 (Halpern, J., concurring).

242. Id. at 72-73 (majority opinion) (quoting testimony of Dr. Meltzer). 
about transgender persons. This displacement comes no more clearly than when Judge Gustafson openly refuses to respect O'Donnabhain's self-perception regarding her gender and employs both feminine and masculine pronouns to refer to O'Donnabhain, depending on whether the reference relates to the period before or after her sex reassignment surgery.

Though they accuse the majority of judicial activism in reaching a decision in favor of partial deductibility for O'Donnabhain's expenses, it is the dissenters themselves who drag this case squarely into the so-called culture war by making up arguments out of whole cloth. Unfortunately, this battle between reactionaries and the LGBT community plays out—however figuratively—on O'Donnabhain's body, as it is laid bare, cut apart, and disfigured by the dissenters' very words. ${ }^{243}$ She emerges from this skirmish with a tax victory, but covered with wounds more literal than literary.

For the LGBT community, the lesson from O'Donnabhain's experience is that the Tax Court is hostile to their claims and to them personally. As explained above ${ }^{244}$ the Tax Court's treatment of LGBT taxpayers in other cases only serves to reinforce this message. ${ }^{245}$ The Tax Court's hostility to LGBT taxpayers further reinforces the ubiquitous hostility toward them found in the Internal Revenue Code, which "encourages gay and lesbian couples not to file returns or statements with the IRS that connect one partner with the other. If they dare to do otherwise, they expose themselves to a panoply of civil and criminal penalties, and, for those in the closet, to the public outing that tax litigation would necessarily entail (should they choose to fight the IRS's determination in court). The Code thus attempts to banish [same-sex] relationships from sight, making [lesbians and gay men] invisible once again." 246

\section{Damage to the Tax System}

On the surface, the tax system - to the extent that it aims to raise revenueemerges having lost revenue, but not as much as it could have. The Tax Court's

243. See id. at 109 (Gustafson, J., concurring and dissenting) (" $[\mathrm{H}] \mathrm{e}$ paid a surgeon about $\$ 20,000$ to remove his genitals, fashion simulated female genitals, and insert breast implants. After these procedures, petitioner 'passed' as female and became happier.").

244. See supra Part II.

245. Even though the Tax Court is an Article I court with specialized jurisdiction, I.R.C. $§ 7441$ (West, Westlaw through P.L. 112-90), its treatment of LGBT taxpayers appears to differ little from that of the generalist Article III courts. A recent empirical study of appellate decisions found that state courts are more receptive to the claims of LGBT litigants than are federal courts. DANIEL R. PINELLO, GAY Rights AND AMERICAN LAW 105-17, 145-46 (2003). Indeed, one commentator has gone so far as to recapitulate the major conclusion of that study as: "federal courts not only were less receptive than state courts to gay rights claims, but that they were systemically hostile." Nan D. Hunter, Federal Courts, State Courts, and Civil Rights: Judicial Power and Politics, 92 Geo. L.J. 941, 942 (2004) (reviewing PINELLO, supra). (It is worth noting that Hunter critiques Pinello's study in her review on both methodological and theoretical grounds.)

246. Infanti, Sodomy Statute, supra note 97 , at 803. 
decision to allow O'Donnabhain a deduction for the bulk of her expenses ${ }^{247}$ namely, those for sex reassignment surgery and hormone therapy-represents a revenue loss. But the denial of a portion of her claimed expenses-namely, those relating to her breast augmentation surgery-represents a revenue gain, especially if one adopts Judge Halpern's position that the denial of this deduction was solely due to a lack of proof. ${ }^{248}$ The largest revenue loss came not from the Tax Court's decision on the merits of O'Donnabhain's claim for a medical expense deduction, but in the Tax Court's later order that the federal government reimburse O'Donnabhain $\$ 250,000$ for her litigation costs. ${ }^{249}$

Again, delving more deeply, the wounds to the tax system extend far beyond what is, in the broader budgetary context, a minuscule loss of revenue. This case strips the tax law of its mantle of exceptionalism. Far from being dragged down from its place above the fray, as Judge Holmes laments, the sharply divided Tax Court in O'Donnabhain merely reveals tax law for what it is, namely, a highly contested political terrain.

Professor Reuven Avi-Yonah has observed that tax academics seem to have a particularly difficult time acknowledging even the most obvious and mundane way in which tax is political. Speaking of the cyclical nature of the tax laws and giving examples of how the current treatment of dividends and capital gains are merely a return to the way in which they were treated in earlier eras, Professor Avi-Yonah asserts:

Tax academics may dismiss this as "just politics" interfering with the desirable progress toward the ideal tax system. But of course, at its heart taxation is all about politics-it is about the relationship between citizens and the state, and about the proper size of the public sector. These are properly the most contested political issues, which come up in every election. To pretend that there is a pure tax science that constantly progresses and that can be separated from these questions is to ignore reality. ${ }^{250}$

Here, Professor Avi-Yonah is really speaking not about the tax system itself, but about the amount of revenue raised by that system. Professor Avi-Yonah is correct that tax is political in the sense that how much revenue we raise through taxation bears on (though is far from determinative of) the question of how large government ought to be. Yet, once they decide how much revenue to raise, politicians have at their disposal a number of different tax instruments to accomplish the goal of raising the desired amount of revenue.

247. The cost of the (nondeductible) breast augmentation surgery was $\$ 4,500$, while the total expenses at issue were more than $\$ 21,000$. O'Donnabhain, 134 T.C. at 41-42 (majority opinion).

248. Id. at 77-78 (Halpern, J., concurring).

249. Order of Decision, O’Donnabhain v. Comm'r, No. 6402-06 (T.C. Nov. 9, 2010).

250. Avi-Yonah, supra note 239, at 2235. 
Tax is thus political not only at the level of determining how much revenue to raise, but also at the level of determining how that revenue is raised. Indeed, this is one of the key insights of critical tax theory. ${ }^{251}$ Consciously or unconsciously, deliberately or reflexively, those who have created and administer our tax system have politicized the collection of revenue by extending into the tax laws - and then entrenching and reinforcing there-the subordination along lines of race, ethnicity, gender, sexual orientation, class, and disability that is pervasive in our society. That pervasive prejudices are pervasively present in the law should not be surprising. It is only surprising to those who embrace the notion that tax is somehow exceptional and who, as a result, falsely believe that the highly charged, endlessly contested topic of taxation is nonetheless above the political fray. ${ }^{252}$

The sharply divided Tax Court in O'Donnabhain put a deep crack in the lenses of the rose-colored glasses worn by tax exceptionalists both inside and outside of academe. It stretches credulity to argue that tax is somehow above the political fray after reading the opinions in this case. The Tax Court majority appears to have distanced itself from the taxpayer-eschewing the demonstrations of empathy encountered in other tax cases involving the boundaries of the medical expense deduction - at least in part, it seems, to fend off accusations of judicial activism. The band of dissenters, who nonetheless sling accusations of judicial activism at the majority, are themselves openly — and simultaneously - activist and reactionary. They go out of their way to make additional arguments on behalf of the government, whose briefs are already bloated and larded with every plausible (and implausible) argument that could be made. In the process, the dissenting Tax Court judges torture both language and law to reach their desired result, while chastising the government for not doing the same. How we impose taxes and administer our tax system simply does not get any more political than that.

Often, the workings of subordination are subtle and insidious. Through control of the flow of ideas in society — what Antonio Gramsci has labeled "hegemony"the dominant group in a society is able to retain and solidify their position through a form of domination that is "often subtle, invisible, and consensual." Though I have provided a fuller description of Gramsci's conceptualization of hegemony elsewhere, ${ }^{254}$ this short recapitulation of the concept nicely highlights its relevance to my point here:

By hegemony Gramsci meant the permeation throughout civil societyincluding a whole range of structures and activities like trade unions,

251. Anthony C. Infanti \& Bridget J. Crawford, Introduction to CRITICAL TAX THEORY, supra note 220 , at xxi.

252. See supra text accompanying notes 86-96.

253. Douglas Litowitz, Gramsci, Hegemony, and the Law, 2000 BYU L. Rev. 515, 519.

254. Infanti, supra note 96 , at 1242-49. 
schools, the churches, and the family_of an entire system of values, attitudes, beliefs, morality, etc. that is in one way or another supportive of the established order and the class interests that dominate it. Hegemony in this sense might be defined as an "organizing principle", or world-view (or combination of such world-views), that is diffused by agencies of ideological control and socialization into every area of daily life. To the extent that this prevailing consciousness is internalized by the broad masses, it becomes part of "common sense"; as all ruling elites seek to perpetuate their power, wealth, and status, they necessarily attempt to popularize their own philosophy, culture, morality, etc. and render them unchallengeable, part of the natural order of things. ${ }^{255}$

With the "organizing principle," "world-view," and "common sense" of a society shaped by its needs and wants, the dominant group in society finds little need for its subordination of others to be blatant or overt. Indeed, it is to the dominant group's great benefit and advantage that many who are subordinated unquestioningly accept their subordination as part of the natural order of things. For this very reason, however, it is remarkable to see O'Donnabhain's subordination lurking not below the surface as some subtle subtext of the Tax Court's decision but being fully on public display. ${ }^{256}$ O'Donnabhain's case has inflicted damage on the tax system and the apparatuses for its enforcement by undermining their image as a neutral mechanism for collecting revenue. Instead, her case reveals tax rules - and the manner in which authority figures interpret and apply those rules - as challengeable, fallible, and actively working to subordinate those not in the dominant group of society.

\section{CONCLUSION}

"Intersectionality." In legal academic circles, we toss this term about in as carefree a fashion as the students at my university toss Frisbees on the lawn behind the Cathedral of Learning on warm spring days. ${ }^{257}$ Though these students are marking their collective joy that the weather has finally begun to warm and that another year in their academic journey is nearly complete, we cannot lose sight of the fact that the ease with which we speak of intersectionality stems not from joy but from repetition-an unthinking repetition that masks a profoundly

255. CARl BogGs, Gramsci's MarXism 39 (1976).

256. In this regard, O'Donnabhain's Tax Court case received much more attention than the typical tax dispute. E.g., Court Rules Sex-Change Costs Are Tax-Deductible, KETK (Feb. 3, 2010, 11:32 AM), http://www.ketknbc.com/news/court-rules-sex-change-costs-are-tax-deductible (last updated Apr. 3, 2011); Ryan J. Donmoyer, Sex-Change Costs Are Tax-Deductible, U.S. Court Rules, Bloomberg (Feb. 3, 2010, 2:47 PM), http://www.bloomberg.com/apps/news?pid=newsarchive\&sid=aqACvUSEeas4; William Saletan, Trans Figure: Should Sex-Change Surgery Be Tax-Deductible, Slate (Feb. 16, 2010, 8:15 AM), http://www.slate.com/id/2244817/.

257. On March 5, 2011, I performed a search for the word "intersectionality" in the "US Law Reviews and Journals, Combined" database on LEXIS, which returned more than 1,500 hits. 
violent phenomenon.

In our short (and, I expect) disturbing time together today, we have removed this and other masks. We have borne witness as the originary violence attendant to the damaging collision of tax with sexual and gender identity carves out an intersection that will provide the opportunity for these two "others" to collide again and again in the future. Yet, despite being "others" of quite different and ostensibly incompatible sorts, we have also seen that tax and sexual and gender identity share in common both their outsider status and a set of severe wounds inflicted by the intersection of their paths. Much as we all understand that redressing discrimination and subordination can be a painful and difficult process, I hope that, by refusing to avert our gaze from the originary, intersectional violence of this collision, we will all have come to more clearly understand that merely acknowledging the existence of discrimination and subordination can be equally painful and difficult—and that we all suffer whenever any one of us is the victim of discrimination or subordination. 